
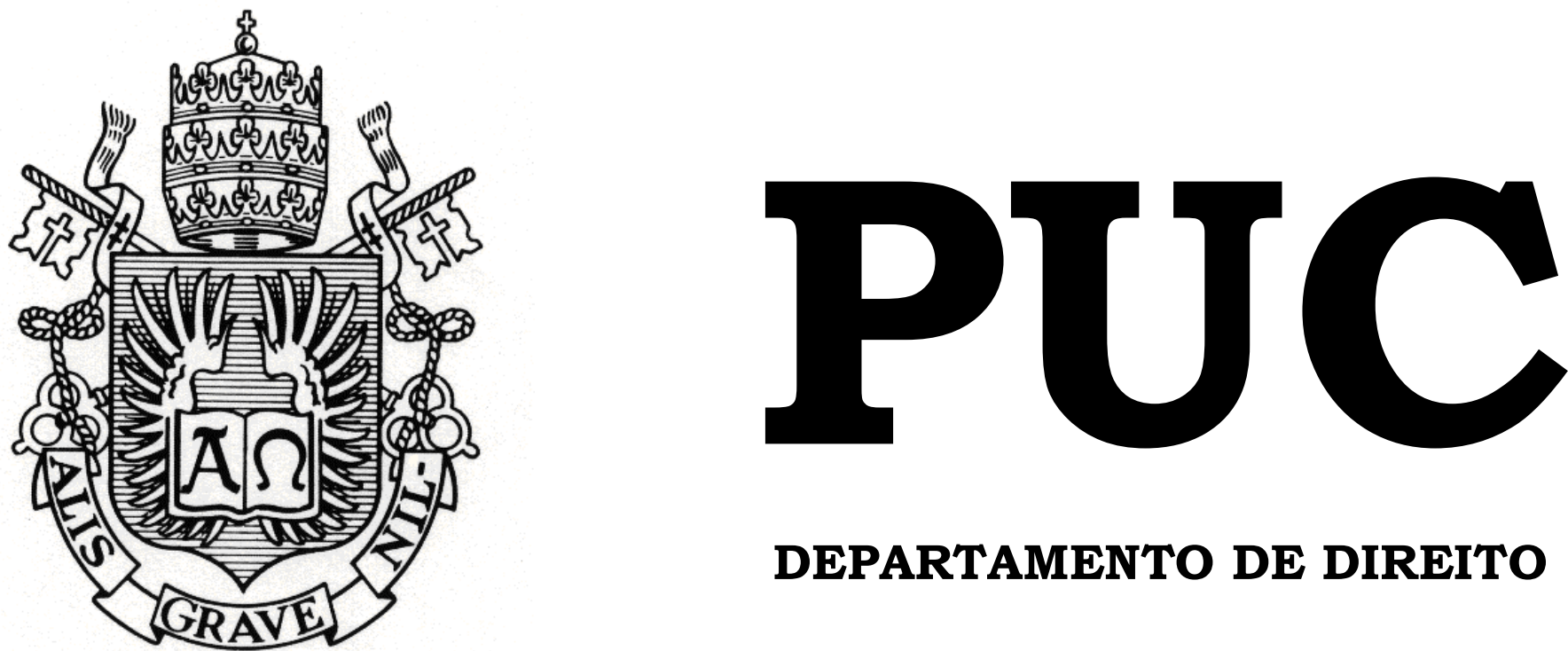

DEPARTAMENTO DE DIREITO

\title{
NATUREZA/CULTURA: UM DUALISMO E SUAS RESSONÂNCIAS NO DIREITO
}

por

Tainá Martins da Costa Gonçalves

ORIENTADOR: Francisco de Guimaraens

2011.2

PONTIFÍCIA UNIVERSIDADE CATÓLICA DO RIO DE JANEIRO

RUA MARQUÊS DE SÃO VICENTE, 225 - CEP 22453-900 
RIO DE JANEIRO - BRASIL

\section{NATUREZA/CULTURA: UM DUALISMO E SUAS RESSONÂNCIAS NO DIREITO}

por

Tainá Martins da Costa Gonçalves

Monografia apresentada ao Departamento de Direito da Pontifícia Universidade Católica do Rio de Janeiro (PUC-Rio) para a obtenção do Título de Bacharel em Direito.

Orientador(a): 


\section{2}

Para Henrique, obviamente. Porque eu prefiro o pôr-do-sol laranja. 


\section{Agradecimentos}

O caminho foi repleto de infortúnios, e certamente não seria possível chegar até aqui, se não fosse a generosidade de muitos.

Agradeço inicialmente a Francisco de Guimaraens e a Fernanda Eugênio: o primeiro por ter me aceito como orientanda (a despeito de minha "organização" caótica) e a segunda pelas sugestões iniciais acerca do "incrível" mundo da antropologia, sem as quais esse trabalho seria impensável.

Igualmente devem ser mencionados: Ronaldo Coutinho, Vivian Assis e Jorge Chaloub, pela gentileza de terem lido e contribuído para a constituição desse trabalho.

À Luciana Tavares Portilho e Daniella Lopes Pessanha, pelas alegrias cotidianas, em meio às "turbulências" do mundo corporativo, que me apoiaram sempre, e foram enfáticas no sentido de que eu não deveria desistir (a contra gosto de meus instantes niilistas).

À Shirley D`Ávila Baron, pela mediação dos afetos (há quase uma década) e por relativizar todas as minhas possíveis "catástrofes" existenciais.

Ao Henrique, pela paciência e, sobretudo, pelo amor- isso já está bom, pois o resto foge às possibilidades da linguagem. 



\section{RESUMO}

O presente trabalho intenciona expor as principais modificações epistemológicas ocorridas na Modernidade, no que diz respeito à divisão entre natureza e cultura, bem como a emergência do método científico a partir desse período histórico, atentando para suas principais conseqüências sociais.

Em seguida, analisa-se o papel das ciências como expressão do dualismo natureza/cultura, além de sua função como legitimador de um discurso de verdade, relativamente aos fatos do mundo natural.

O Direito, por sua vez, será inserido na referida discussão de duas formas: em primeiro lugar como herdeiro desse paradigma, a través do Positivismo de Hans Kelsen. Em um segundo momento, como resposta (através do Direito Ambiental) às conseqüências ambientais advindas das relações nem sempre harmônicas que o homem estabeleceu com o meio ambiente.

A abordagem escolhida será utilizada para demonstrar os impasses da referida divisão, evidenciando a necessidade de uma nova regulação da vida em comum entre os seres humanos e natureza. Nesse, sentido, ressalta-se o papel do Direito (em especial o Direito Ambiental) como possibilidade (mas também como impasse) de efetivar essa regulação.

PALAVRAS- CHAVE: Natureza, Cultura, Modernidade, Direito 



\section{SUMÁRIO}

Introdução...

\section{Capítulo 1- Modernidade, Ciência e Cultura}

1.1Modernidade.

1.2Cultura.

1.3 A ciência e suas questões

\section{Capítulo 2- Modernidade e Direito}

2.1 Modernidade e Positivismo Jurídico

2.2 Kelsen e o paradigma dominante no direito.

2.3 Direito Ambiental: possibilidades e impasses.

Conclusão 


\section{Introdução}

A relação dos homens com tudo o que não é humano sofre intensas modificações a partir da Modernidade e nos períodos posteriores. Dentre as muitas mudanças ocorridas a partir desse período histórico, há uma que diz respeito à total separação entre as questões da natureza, de um lado e as questões da cultura, do outro.

Por Modernidade, entende-se o período histórico subseqüente à Idade Média, definido por duas "propostas" de ruptura com o medievo: a primeira, caracterizada pelo renascimento e pela afirmação da imanência absoluta e a segunda, vencedora, diga-se de passagem, ainda baseada na transcendência e na mediação como forma de reprimir o conhecimento advindo da experiência imediata dos seres humanos com o meio.

Assim, se de um lado, "os seres humanos se declararam donos de suas próprias vidas, produtores de cidades e da história e inventores dos céus" (HARDT e NEGRI, 2001, p.89), de outro, continuaram demandando a transcendência em sua relação com o mundo, demanda essa que acabou prevalecendo enquanto projeto moderno - o presente trabalho se propõe a analisar essa segunda modernidade vencedora.

Já a cultura a que se faz referência, apesar da polissemia e da historicidade do termo (que se pretende expor adiante), pode ser compreendida, em linhas gerais, como um conjunto de características comportamentais inerentes exclusivamente aos seres humanos, que os distingue da natureza e dos outros seres nela existentes ${ }^{1}$.

A natureza, por sua vez, a partir da Modernidade, "é tão só extensão e movimento, é

\footnotetext{
${ }^{1} \mathrm{O}$ dualismo a que se está fazendo referência será fundamental à compreensão da forma como o homem é pensado a partir da Modernidade. Inicialmente cabe destacar que as concepções filosóficas emergentes nesse período histórico atribuíram um estatuto superior às características humanas que expressam a cultura. Um exemplo disso pode ser encontrado na teoria cartesiana acerca da relação entre a mente e o corpo.Em linhas gerais, a concepção de Descartes afirma ser a mente o lugar da vontade livre e racional, expressa através do pensamento. 0 corpo, por sua vez, está intimamente submetido às relações de causalidade da natureza, uma vez que encerra em si as dimensões biológicas dos seres humanos- observa-se, então, a necessidade de que as expressões do corpo sejam controladas pela mente.
} 
passiva, eterna e reversível mecanismo cujos elementos se podem desmontar e depois se relacionar sob a forma de leis" (SANTOS, 2003, p. 25), ou nas palavras de Marilena Chauí "organização universal e necessária dos seres, segundo uma ordem regida por leis universais e necessárias" (CHAUI, 2003, p. 288).A natureza, de acordo com tal concepção, estaria sujeita a constância e inevitabilidade das relações causais entre os seres.

Assim, o homem, em tal contexto situa-se no segundo ponto (da cultura), distinguindo-se dos não humanos por ser dotado de vontade racional e livre, não estando unicamente relacionado às leis de causalidade inerentes à natureza, que "não tem qualquer outra qualidade ou dignidade que nos impeça de desvendar os seus mistérios, desvendamento que não e contemplativo, mas antes activo, já que visa conhecer a natureza para a dominar e controlar (SANTOS, 2003 , p. 25).

A descoberta dessa autonomia frente às relações de causalidade presentes na natureza ocasionou uma mudança radical da posição do homem: da concepção de natureza mítica dos tempos primevos, passou-se a natureza dada ao conhecimento do homem, que tem na razão e no pensamento sua causa de existir, nos termos do cogito cartesiano. ${ }^{2}$

Ocorre que a relação de dominação estabelecida entre o homem moderno e essa nova natureza ira ocasionar situações indesejadas para ambos, cujas conseqüências se apresentam na atualidade, quais sejam as catástrofes ambientais, que possuem desdobramentos trágicos não somente para a natureza, como também para os seres humanos ${ }^{3}$.

Vamos nos ater às decorrências dessa divisão, no que diz respeito aos discursos surgidos

\footnotetext{
${ }^{2}$ Sobre a relação entre o homem e a natureza antes do advento da Modernidade, bem expõe Juan Ramon Capella: "Para a humanidade primitiva, durante um lapso temporal muito prolongado a respeito do qual nossa memória histórica coletiva aparece como um breve momento, a Natureza era um ente caprichoso e ameaçante, sobre o que se projetava a espiritualidade, a capacidade reflexiva e artefactora que o mundo chegou a pôr em prática precisamente na espécie humana. A natureza estava dotada de intenções para o homem primitivo, cheia de signos; era mágica, sagrada- assim mostrou a obra de Eliade.Sua lógica fenomênica se percebia com a atuação de deuses, de seres mais poderosos que os humanos.Certa atitude emocional ante a Natureza, o amor a suas forças "benfeitoras" - porque nos adaptamos a elas e esperamos sua atuação- e o terror antes as catastróficas - quando seguem-se mostrando-se como ingovernáveis: as epidemias, as calamidades naturais - segue presente em nós.Apesar de conhecermos bastante a lógica geral do cosmo, a despeito de parecermos dominara a Natureza, compreendemos, ainda que seja vendo-a explicativamente, a concepção que dela tinham nossos antepassados remotos. (CAPELLA, 1988, p.161-162)
} 
durante a Modernidade e nos períodos seguintes para melhor compreender os termos da questão: o dualismo aqui referido inaugurou um paradigma epistemológico absolutamente singular, que separa o sujeito do conhecimento (o homem) do objeto desse mesmo conhecimento (inicialmente, a natureza e depois as ciências sociais), a fim de garantir um resultado universal acerca do estudo desse objeto, que será obtido em qualquer tempo e lugar, eis que não está submetido às intencionalidades de seu observador, pois a ele cabe tão somente analisar as propriedades intrínsecas desse objeto- a isso chamaremos de "ciência moderna".

Já no século XIX, com o surgimento das ciências sociais, o referido modelo, a que Boaventura Sousa Santos denominar "paradigma dominante" será igualmente imposto aos estudos destinados à analise dos fenômenos sociais, ainda que com o reconhecimento das dificuldades inerentes a essa transposição (da epistemologia das ciências naturais para as ciências sociais), uma vez que essas não se objetivavam facilmente, e estavam muito mais propensas à subjetividade de seu observador. Ainda assim, as ciências sociais não conseguiram, de início um estatuto epistemológico próprio.

Observa-se então que a divisão entre natureza e cultura estabeleceu-se na maior parte dos discursos da Modernidade e de momentos posteriores, legitimando, contudo, algumas práticas que, além de indesejáveis para a humanidade evidenciaram a inconveniência da própria divisão, ou, ao menos a possibilidade de abalá-las de diversas formas, não para dizer que tal divisão não exista, pois "já há coisas demais que não existem" (VIVEIROS DE CASTRO, 2008, p. 365), mas para repensar sua utilidade, bem como o que ela diz acerca da relação que o homem moderno estabeleceu com os "outros" (não humanos).

O Direito, nesse contexto, aparecerá sob duas formas: seja em um primeiro momento como herdeiro desse paradigma dominante, quando juristas como Hans Kelsen desejam o reconhecimento de uma "ciência jurídica", e, de outra forma como meio de regulamentar as relações entre os seres humanos e a natureza, quando essas relações já não são livremente harmônicas, através do Direito Ambiental, o que certamente evidencia os impasses da divisão

\footnotetext{
${ }^{3}$ Novamente, Capella nos ensina (CAPELLA, 1988, p.48): Pois essa natureza da llustração se sonha dominável. Sobre ela se pode exercer, submetendo-a, o senhorio da vontade humana(...).E essa natureza tão ideologicamente vista vai ser, precisamente, o lugar do excesso, o lugar da atuação das forças dionísicas, o lugar da industrialização.
} 
natureza/cultura em suas conseqüências epistemológicas e políticas.

Nesse sentido, tem-se inicialmente a disciplina jurídica fechada em si mesma, negando toda e qualquer influência política e social no estudo da "ciência jurídica", a fim de garantir sua autonomia frente à sociologia e à história, e igualmente sua cientificidade, com o intuito de ser reconhecida como ciência, o que levará Kelsen a afirmar que "A Teoria Pura do Direito (....) como teoria , quer única e exclusivamente conhecer seu próprio objeto (...)Quando a si própria se designa como "pura" teoria do Direito, isto significa dizer que ela pretende libertar a ciência jurídica de todos os elementos que lhe são estranhos. Este é seu princípio metodológico fundamental". (KELSEN, 2003,p. 9)

Por outro lado, o Direito não será apenas influenciado pelo "paradigma dominante", uma vez que terá de viabilizar as relações desregulamentadas, decorrentes da dominação da natureza pelo homem, a fim de garantir a sobrevivência de ambos, através de instrumentos normativos (tanto de direito material, quanto de direito processual), destinados à tutela do meio ambiente, que se apresenta, em última análise, como meio de proteger igualmente a própria espécie humana.

Todavia, a emergência de um mecanismo regulamentador das relações entre os humanos e os não humanos não virá livre de contradições e pressupostos ainda inerentes ao paradigma dominante. A proteção ao meio ambiente é, antes de mais nada, uma forma ainda antropocêntrica de se pensar a relação "humanos- outros", pois para além das utopias ambientalistas, de retorno ao estado de natureza rousseauniano, a fim de preservar o meio ambiente, está a intervenção do Estado (por meio do Direito), que apenas serve como meio de instituição das "regras" do jogo de dominação da natureza que não cessa.

O presente trabalho se propõe a analisar a divisão natureza/cultura em suas dimensões conflitivas e em seus desdobramentos (inclusive jurídicos), atentando para a importância de se criar outra gestão para um mundo comum, onde não só os que se dizem humanos habitam.

Modernidade, ciência e direito necessitam ser recolocados e estendidos em alguns de seus aspectos mais potentes, através de novas práticas, sem dúvida muito distantes das que se legitimaram a partir daquele período histórico, mas com caminhos possíveis, sendo o primeiro passo para pensá-los, relativizar o que se naturalizou, a saber, a relação que os modernos 
estabeleceram com os "outros". Nesse sentido, o fenômeno foi bem pontuado por Boaventura Souza Santos: "A consagração da ciência moderna nestes últimos quatrocentos anos naturalizou a explicação do real, a pontos de não o podermos conceber senão nos termos por ela propostos" (SANTOS, 2003, p. 84)

Destacam-se dois aspectos para a análise: em um primeiro momento, será exposta a influência do dualismo já mencionado para o método jurídico na obra de Hans Kelsen, autor referência do "positivismo jurídico".

Posteriormente, será analisada a "resposta" dada pelo direito às conseqüências sociais do pensamento dualista na natureza, que possibilitou a dominação desta pelos seres humanos, de maneira catastrófica, de onde emergiu a necessidade de regulamentação da relação entre o homem e a natureza, materializada nas normas de direito ambiental, não sem se esquecer de apontar os "impasses" inerentes a essa mesma regulamentação.

A escolha da análise propõe igualmente uma discussão sobre o status do discurso científico no mundo moderno, que se sobrepõe a toda e qualquer outra forma de conhecimento. Nesse sentido, o fio condutor do trabalho passaria pela análise entre direito e ciência, pois:

O direito precede a ciência, e, talvez, a engendre; ou melhor: uma origem comum abstrata os reúne. Antes dela só se pode imaginar o dilúvio,a grande enchente, primeira ou recorrente das águas, ou seja, esse caos que mistura as coisas do mundo, as causas, as formas, as relações de atribuição e que confunde os sujeitos. Dir-se ia o estado contemporâneo de nossos problemas. (SERRES, 1992, p. 69)

No desenvolvimento deste trabalho foi realizada uma pesquisa que tem como marco teórico as obras do sociólogo Bruno Latour, "Jamais Fomos Modernos" e "Políticas da Natureza: como fazer ciência na Democracia", para a devida dimensão das "inconveniências" referentes à total separação entre natureza e cultura operada a partir da Modernidade.

O referido autor em muito auxiliou no entendimento dos principais debates ambientais e científicos, que são alvo de inúmeras discussões na atualidade, evidenciando a diversidade de "soluções" e de abordagens sobre a questão ambiental. Obras de antropólogos foram igualmente esclarecedoras, em especial, de Eduardo Viveiros de Castro, que, através, da análise de "culturas" muito distantes da civilização ocidental, expondo os "pontos epistemológicos sensíveis" dessa mesma civilização. 
Além disso, foi necessário atentar para os conceitos de natureza e de cultura, bem como para o "modo de uso" desses conceitos ao longo dos debates epistemológicos, para a devida compreensão das dificuldades que se apresentam nos dias atuais, em termos de gestão dos problemas ambientais, que, sem dúvida, está relacionada aos pressupostos epistemológicos modernos.

Para o cumprimento da exigência (não pouco óbvia) de inserção de uma questão jurídica na conclusão do curso de Direito, inicialmente foi intentada a leitura do jurista Kelsen, que somente pode ser minimamente compreendidas à luz dos esclarecimentos de Norberto Bobbio.

Posteriormente, e ainda em âmbito jurídico, a análise da emergência do Direito Ambiental mostrou-se fundamental para pensar os limites e as possibilidades desse ramo do direito diante da exigência de uma regulamentação das relações entre os humanos e os não humanos, em que ambas as partes sejam beneficiadas.

Os resultados da pesquisa apontam para a necessidade de redefinições epistemológicas urgente, tendo em vista os desastres ambientais (e também humanos), que ocorrem cada vez mais, bem como igual redefinição das possibilidades de construção de um mundo comum, onde "todos" (humanos e não humanos) possam ter voz.

\subsection{Modernidade}

O presente capítulo irá expor as principais características da Modernidade, que definem esse período histórico como uma "nova ordem" (política e filosófica) frente a organização (política e filosófica ) do medievo.

Inicia-se o presente capítulo com o argumento de Hardt e Negri, segundo o qual a Modernidade se constituiu a partir de duas propostas distintas, tendo sido uma delas vencedora ${ }^{4}$. A escolha desse "ponto de partida" na abordagem do tema é fundamental para que se entenda os

\footnotetext{
${ }^{4}$ A modernidade não é um conceito unitário, mas aparece, de preferência, em dois modos.O primeiro modo é o que já definimos, um processo revolucionário radical.Essa modernidade destrói suas relações com o passado e declara a imanência do novo paradigma do mundo e da vida.Desenvolve conhecimento e ação como experiência científica e define uma tendência à experiência democrática, colocando humanidade e desejo no centro da História.Do artesão ao astrônomo, do mercador ao político, na arte como na religião, o material da existência é reformado por uma vida nova.(HARDT e NEGRI, 2001,p. 93)
} 
termos da crítica aqui feita ao período Moderno, pois se entende que esse "embate" inicial de forças é decisivo para a devida compreensão dos impasses inerentes às "promessas" da Modernidade.

Assim, tem-se com o advento desse novo período histórico a emergência de forças da imanência, que afirmam os poderes deste mundo, atribuindo ao homem a capacidade de conhecer através da experimentação, bem como de exorcizar toda forma de mediação: fala-se direitamente a Deus, o conhecimento advém da experiência imediata e a participação política é constituída diretamente pela multidão. A afirmação do plano de imanência, "tudo ao mesmo tempo e agora", se dá em todos os âmbitos, evidenciando a ruptura com o medievo, bem como a impossibilidade de retorno às bases do pensamento medieval.

Mas essa descoberta dos poderes desse mundo, por sua vez, originou uma série de conflitos, pois não foi evidentemente recebida pelas "instâncias superiores" de forma pacífica- era necessário conter a multidão, mas tal não poderia ser feito com retorno ao Medievo, mas sim, como novos rearranjos da transcendência ${ }^{5}$. A multidão possuía evidentemente um desejo de libertação, mas foi vencida pelo medo e insegurança- a paz tornou-se o grande chavão da transcendência contra o desejo desenfreado, movido pela imanência. Nas palavras de Hardt e Negri (HARDT e NEGRI,2001, p. 93): “a paz tornou-se a condição miserável de sobrevivência, a urgência extrema para escapar da morte. A paz foi marcada simplesmente pela fadiga da luta e a usura das paixões.."

Feita essa consideração inicial, parte-se para o "interior" da Modernidade, com destaque para alguns de seus acontecimentos significativos, para posterior exposição de seus impasses.

A Modernidade se coloca como uma ruptura, relativamente ao passado-liberados da religião enquanto lugar por onde a explicação do mundo necessariamente deveria passar, os

\footnotetext{
${ }^{5}$ O que está em jogo é uma nova forma de mediação, ou, mais exatamente, um esmorecimento reflexivo e uma espécie de débil transcendência, que relativiza a experiência e abole todas as instâncias do imediato e do absoluto na vida e na História humana. Entretanto, porque a relatividade é necessária? Por que o conhecimento e a vontade não podem se proclamar absolutosc Porque cada movimento de autoconstituição da multidão deve ceder à ordem pré constituída, e porque sustentar que seres humanos podem estabelecer de imediato sua liberdade de existir seria um delírio subversivo.Esse é o âmago da transição ideológica sobre a qual o conceito hegemônico de modernidade foi construído. (HARDT e NEGRI, 2001, p. 96-97)
} 
indivíduos são capazes de criticar o obscurantismo dos antigos poderes ao "descobrirem" os fenômenos naturais que esses ocultavam.

Grande parte dessa liberação só foi possível devido a alguns acontecimentos históricos que marcaram a Modernidade. A Reforma, nesse sentido, pode ser considerada o acontecimento fundamental para o enfraquecimento do poder político da Igreja Católica e o conseqüente fortalecimento do poder político dos governantes dos Estados Modernos- é nessa nova ordem que o conhecimento científico terá relativa liberdade para se desenvolver, uma vez que não terá mais de temer os poderes da Igreja ${ }^{6}$.

Nesse contexto, o passado é visto como algo a ser superado e desconsiderado, pois a ausência de conhecimento das idades passadas, que misturava indevidamente a "realidade, representada pela natureza, e as demandas sociais (partes do "mundo" da cultura) foi substituída pela perspectiva iluminista que pregava a separação absoluta entre ambas.

Isso se intensifica com o surgimento das ciências humanas no século XIV, que, estudando os fenômenos sociais eram capazes de distinguir entre o "científico" e o que era devido à ideologia ${ }^{7}$.Tal fato se expressa nitidamente no engajamento dos modernos no que diz respeito à distinção entre o racional e o irracional,entre os "falsos saberes" e as "verdadeiras ciências.

\footnotetext{
${ }^{6}$ Como expõe Quentin Skinner: (...) a aceitação da idéia moderna de Estado pressupões que se reconheça que a sociedade política existe unicamente para fins políticos. Seria impossível aceitar essa perspectiva secularizada enquanto se supôs que todos os governantes temporais tivessem o dever de zelar por um governo leal e um Deus pacífico. Os reformadores do século XVI concordavam plenamente com seus adversários católicos nesse aspecto: todos insistiram em que um dos principais objetivos do governo deveria ser o de apresentara "verdadeira religião" e a Igreja de Cristo.Como vimos, isso significa, por sua vez, que as convulsões religiosas da Reforma deram uma contribuição paradoxal, e no entanto vital, para cristalizar-se o conceito moderno e secularizado de Estado.Isso porque, assim que os defensores de credos religiosos rivais se mostraram dispostos a travar entre si um combate de morte, começou a evidenciar-se, aos olhos de diversos teóricos da linha polithique, que, para se ter alguma perspectiva de obter a paz cívica, os poderes do Estado teriam de ser desvinculados do dever de defender uma determinada fé. (SKINNER, 1996, p. 620)

${ }^{7}$ O conceito de ideologia comporta inúmeros significados ao longo da história, bem como de acordo com a colocação de diferentes autores. O registro importante a ser feito aqui diz respeito aos efeitos que uma determinada "idéia" do conceito de ideologia,que remete à diferença entre "as coisas em si" versus"o uso que os humanos fazem delas nas relações entre eles". Nesse sentido,cabe destacar as idéias de Karl Marx acerca do conceito.Nas palavra de Michel Lowy: "Em A Ideologia Alemã, o conceito de ideologia aprece como equivalente à ilusão, falsa consciência,concepção idealista na qual a realidade é invertida e as idéias aparecem como motor da vida real.(...)".LOWY, 2003.p.11).Evidentemente, não se pretende lançar uma questão acerca do tema, tampouco expor a história do conceito. Para maiores detalhes do conceito de ideologia,ver: LOWY,2003
} 
O que é feito através dessa prática?A separação entre os sujeitos e os objetos, os fatos e os valores, os dados dos construídos, a natureza das culturas. Em que medida a "crítica "moderna é potente e quase imbatível?Ao separar as relações de força de ordem política das razões de ordem científica, mas sempre legitimando a razão através das relações de força e a força através da razão, os modernos tiveram muitas possibilidades. Como propõe Bruno Latour (LATOUR, 2004, p. 67):

Você acredita que o trovão é uma divindade?A crítica irá mostrar que trata-se,nesse caso de mecanismos físicos sem influência sobre os acontecimentos do mundo humano.Você está preso a uma economia tradicional?A crítica irá mostrar que mecanismos físicos podem transformar a evolução do mundo humanos ao mobilizarem gigantescas forças produtivas. Você acredita que os espíritos dos ancestrais o prendem eternamente a suas leis?A crítica irá mostrar que os espíritos são construções sociais que você criticou para si mesmo. Você está indignado porque o mundo está sendo mecanizado?A crítica irá falar sobre o deus criador ao qual tudo pertence e que deu ao homem todas as coisas. Você está indignado que a sociedade seja laica?A crítica irá mostrar que a espiritualidade foi libertada por esse laicismo, e uma religião completamente espiritual é bem superior. Você pensa ser religioso?A crítica irá rir de você até não poder mais!

Esses são os múltiplos discursos existentes na modernidade hegemônica e que certamente ensejam mais uma mistura do que uma separação entre "as coisas em si" versus "a sociedade. 0 que se pode observar é a formação associação entre humanos e não humanos por todas as partes, o que, contudo, não foi considerado.

Tal impossibilidade de se pensar essas associações (uma vez que os modernos compreendem o mundo a partir da divisão natureza/cultura) acabou por gerar uma proliferação desregulada dessas associações, que tem como conseqüência acontecimentos cada vez mais indesejados, a exemplo dos desastres ambientais e, em uma dimensão maior, o aquecimento global. Onde começa a natureza e termina a sociedade nessas questões?Quem, em última análise, é responsável por elas?

Esses questionamentos ilustram como existem inúmera associações arriscadas entre o homem e a natureza, que, longe de serem impensáveis, necessitam de reconhecimento e posterior regulamentação, para uma convivência segura a ambas as partes (humanos e não humanos).

A partir desses acontecimentos, já se pode vislumbrar uma crítica às "promessas" da modernidade vencedora- a história caminhou rumou ao progresso?Talvez, mas não só. 
Deve-se ter em mente que a história apenas selecionou os eventos a serem expostos, pois o tempo é feito a partir da seleção dos acontecimentos e essa forma de viver o tempo a partir da Modernidade ${ }^{8}$ sugeriu um progresso, que não veio desacompanhado de inúmeros fracassos.

O tempo é, na verdade, um resultado instável de ligação entre os seres ${ }^{9}$ e é essa ligação que o constitui e não a história tal como é contada, pois essa indica apenas uma das muitas ligações existentes. Tem-se o conhecimento de acontecimentos selecionados, que parecem indicar um avanço contínuo e linear, mas e quanto aos refugos?Houve uma ruptura com a ordem anterior, baseada na transcendência de forma que essa ordem não deva ser considerada?

Observa-se, nesse sentido, que o mundo moderno permite continuidade de práticas anteriores, além de inúmeros rearranjos de antigas crenças. Analisados esses aspectos, pode-se então relativizar a modernidade enquanto ruptura, pois existe uma diferença entre as diversas "propostas" de Modernidade e o que se passou de fato, havendo, com isso, a necessidade de se repensar os paradigmas ainda vigentes, que emergiram nesse período histórico.

Assim, "Jamais Fomos Modernos", como bem sugere Bruno Latour, porque a Modernidade é em seu conceito, uma crise, e o projeto vencedor jamais conseguiu se impor no

8 Pode-se confrontar dois pensamentos em face de história: o moderno e o das civilizações tradicionais.SegundoMirceaEliade: há "o homem histórico(moderno)que se sabe e que se quer criador da história" e o homem das civilizações tradicionais, que "não atribuía ao acontecimento histórico um valor em si,isto é,não o via como uma categoria específica do seu próprio modo de existência". Cabe, contudo, uma ressalva importante: o homem que se reconhece e se quer sujeito histórico não é o único que existe na Modernidade..Tem-se nesse aspecto ,outros comportamentos face a história coexistentes...Novamente, MirceaEliade pontua: “(...)atualmente o mundo moderno não foi conquistado pelo historicismo;assiste-se mesmo ao conflito entre duas concepções:a concepção arcaica, que designaríamos por arquetípica e anti-histórica e a moderna pós-hegeliana,que se quer histórica(...)." (ELIADE,1993,p.153)

\footnotetext{
${ }^{9}$ Aaron Gourevitch, citado por Maria Rita Kehl pontua a importância da percepção do tempo ao longo de diferentes momentos históricos e culturas. Em suas palavras: "As representações do tempo são componentes essenciais da consciência social, cuja estrutura reflete os ritmos e as cadências que marcam a evolução da sociedade e da cultura.O modo de percepção e de apercepção do tempo revela inúmeras tendências fundamentais da sociedade e das classes,grupos e indivíduos que as compõem.O tempo ocupa um lugar de primeiro plano no "modelo do mundo" caracteriza esta ou aquela cultura,tanto quanto outros componentes desse "modelo" como o espaço, a causa, a mudança,o número, a relação entre o mundo sensível e o mundo supra-sensível,a relação do particular ao geral e da parte ao todo,o destino, a liberdade,etc."(GOUREVITCH apud KEHL, 2009.p.111)

${ }^{10}$ Aqui cabe uma explicação acerca da proposta de Bruno Latour na obra citada. Em suas palavras:(...) A hipótese desse ensaio- trata-se de uma hipótese e também de um ensaio- é que a palavra "moderno" designa dois conjuntos de práticas totalmente diferentes que, para permanecerem eficazes, devem permanecer distintas, mas que recentemente
} 
plano do real sem a resistência do plano de imanência, que a todo momento evidenciou os impasses da Modernidade Hegemônica, a invasão dos "híbridos ${ }^{11 "}$ na pureza metodológica e na separação total entre os humanos e os não humanos.

\subsection{Cultura}

Para a devida compreensão da crítica que se intenta fazer ao dualismo natureza/cultura, entende-se ser necessário expor como essa palavra pode ser entendida a partir da Modernidade.

Inicia-se o presente capítulo, com a exposição dos significados primitivos da palavra cultura, elucidando sua mudança ao longo do tempo, com vistas a evidenciar a referida mudança de acordo com a história das idéias, pois a mudança semântica de tal palavra muito nos diz acerca dos acontecimentos históricos, como se tentará demonstrar ${ }^{12}$.

deixaram de sê-lo.o primeiro conjunto de práticas cria, "por tradução", mistura entre gêneros de seres completamente novos, híbridos de natureza e cultura.O segundo cria, por "purificação", duas zonas ontológicas inteiramente distintas, a dos humanos, de um lado, e a dos não humanos, de outro.Sem o primeiro conjunto, as práticas de purificação seriam vazias ou supérfluas.Sem o segundo, o trabalho de tradução seria freado, limitado ou mesmo interditado.(...) Enquanto considerarmos separadamente estas práticas, seremos realmente modernos, ou seja, estaremos aderindo sinceramente ao projeto da purificação científica, ainda que este se desenvolva somente através da proliferação dos híbridos .A partir do momento em que desviamos nossa atenção simultaneamente para o trabalho de purificação e o de hibridação, deixamos de ser modernos nosso futuro começa a mudar.Ao mesmo tempo deixamos de ter sido modernos, no pretérito, pois tomamos consciência, retrospectivamente, de que os dois conjuntos de práticas estiveram operando desde sempre no período histórico que se encerra.Nosso passado começa a mudar.Enfim, se jamais tivéssemos sido modernos, pelo menos não da forma como a crítica nos narra, as relações tormentosas que estabelecemos com as outras naturezas-culturas seriam transformadas.(LATOUR, 2009, p. 16)

11 "Híbrido" é a palavra utilizada por Bruno Laotur designar as associações entre humanos e não humanos queevidenciam a impossibilidade de separação entre questões da natureza e questões da cultura. Para maiores detalhes, ver LATOUR, 2009.

12 Assim se pode retraçar paralelamente à história da semântica, isto é, a gênese das diferentes significações da noção de cultura, a história social destas significações: as mudanças semânticas, aparentemente de natureza 
Evidentemente, não se trata de fazer um inventário de todos os significados que a palavra cultura já possuiu, mas apenas aqueles que sugerem apropriações do conceito de cultura para a história das idéias- a seleção de significados, nesse sentido foi feita de forma um tanto arbitrária, pois se trata de pensar o referido conceito em sua relação com a história das idéias.

Inicialmente, tem-se o significado de raiz latina da palavra, designando "o cultivo, e que chega, por exemplo, a transferir-se para a cultura da terra-a indicação mais exata de seu caráter formativo,instrumental e material"(AGOSTI,1984,p. 10)- tal significado da palavra "cultura" ainda estava longe de sugerir uma entidade ou estar relacionada a uma faculdade do espírito-apenas em meados do século XVI a palavra será utilizada em sentido figurado "e "cultura" pode designar então uma faculdade, isto é , o fato de trabalhar para desenvolvê-la" (COUCHE, 2003, p. 19) ${ }^{13}$.

Por sua vez, o século XVIII pode ser considerado o século de constituição sentido moderno da palavra: ela vai fazer parte do vocabulário do lluminismo, sendo entendida como "estado" do espírito que é cultivado pela instrução, estado do indivíduo que tem cultura, resultado da formação e da educação dos seres humanos, expressos em obras, ações, instituições (COUCHE, 2003, p. 64)- esse seria o significado inicial da palavra a ser destacado. Assim, o primeiro uso de "cultura" remonta ao sentido francês da palavra no século XVIII, que designa a universalidade dessa característica distintiva da humanidade e,por isso, seu uso no singular- em tal contexto, a

puramente simbólica, correspondem em realidade a mudanças de uma outra ordem. Correspondem a mudanças na estrutura das relações de força, entre, de um lado, as sociedade em relação de interação, isto é, mudanças nas posições ocupadas pelos diferentes parceiros interessados em definições diferentes de cultura".(SAYD apud COUCHE,2003, p. 12)

13 Aqui nos antecipamos em expor uma conclusão de extrema relevância, no sentido de aprofundar a questão etimológica da palavra cultura, utilizando a importante observação de Terry Eagleton: "A raiz latina da palavra cultura é colere, o que pode significar qualquer coisa, desde cultivar e habitar a adorar e proteger.Seu significado de "habitar" evoluiu do latim colonus para o contemporâneo colonialismo, de modo que títulos como cultura Cultura e colonialismo são de novo, um tanto tautológicos. Mas colere também desemboca, vão o latim cultus, no termo religioso "culto", assim como a própria idéia de cultura vem na Idade Moderna a colocar-se no lugar de um sentido desvanescente de divindade e trancendência.Verdades culturais,- trate-se da arte elevada ou das tradições de um povo- são algumas vezes verdades sagradas, a serem protegidas e reverenciadas.A cultura, então, herda o manto imponente da autoridade religiosa, mas também tem afinidades desconfortáveis com ocupação e invasão; é entre esses dois pólos, positivo e negativo, que o conceito, nos dias de hoje, está localizado.Cultura é uma dessas raras idéias que têm sido tão essenciais para q esquerda política quanto são vitais para a direita, o que torna sua história social excepcionalmente confusa e ambivalente." (EAGLETON,2003 p 10-11). 
palavra terá significado próximo ao de "civilização", utilizada para expressar os progressos coletivos da humanidade ${ }^{14}$.

Nesse momento histórico, a cultura será oposta a natureza e tal oposição é fundamental para os pensadores do iluminismo, que concebem a cultura como característica que distingue a espécie humana de todas as outras- cultura será utilizada no singular e característica distintiva do Homem que o lluminismo conceituou. Considera-se que a natureza opera por causalidade, de acordo com leis necessárias de causa e efeito, enquanto o homem é dotado de liberdade e razão, agindo por livre escolha e, por isso, capaz de produzir cultura, ao contrário da natureza que já estava sempre "dada".

Além disso, a cultura no pensamento iluminista estará ligada às idéias de progresso e de evolução- através do homem racional de espírito "cultivado", é possível intervir nas relações de causalidade e modificá-las rumo ao progresso ${ }^{15}$.

Todavia, o termo será apropriado de maneira distinta nos territórios francês e alemãoexposta a apropriação no primeiro estado (a França), passa-se a narrativa de como "cultura" foi utilizada em território alemão.

Inicialmente cabe destacar que, em um primeiro momento, o uso do termo cultura na Alemanha será quase que idêntico ao seu uso na França- a utilização do Francês como marca distintiva da nobreza explica tal apropriação.

Todavia, a categoria "Kultur" irá em pouco tempo adquirir um significado mais bem sucedido, distinto de sua homóloga em francês.Nos termos da explicação de Denys Couche (COUCHE, 2003, p. 24):

\footnotetext{
14 Em síntese: "O uso de cultura e de civilização no século XVIII marca então o aparecimento de uma nova concepção dessacralizada da história.A filosofia $\mathrm{d}(\mathrm{da}$ história se libera da teologia(da história).As idéias otimistas de progresso,inscritas nas noções de "cultura " e de civilização" podem ser consideradas como uma forma de sucedâneo de esperança religiosa.A partir de então,o homem está colocado no centro do universo." (COUCHE,2003, p.17)

${ }^{15}$ Nesse contexto, a relação o que os homens estabelecem com o tempo, com outros seres e com a natureza será influenciada por tal pensamento. A distinção entre natureza e cultura passa a considerar como o tempo se realiza na natureza: sob a forma de repetição (as relações de causalidade sempre produzindo os mesmos efeitos) e o tempo da cultura- o da transformação, o das mudanças, rumo ao progresso, visto ser o racional e dotado de vontade livre, capaz de intervir no destino e, por isso, mudar a história.
} 
“(...) este sucesso é devido à adoção do termo pela burguesia intelectual alemã e ao uso que ela faz dela na sua oposição à aristocracia da corte. De fato, contrariamente, à situação francesa, burguesia e aristocracia não têm laços estreitos na Alemanha.A nobreza é relativamente isolada em relação às classes médias, as cortes principescas são muito fechadas, a burguesia é afastada , em certa medida, de qualquer ação política.Esta distância social alimenta um certo ressentimento , sobretudo entre muitos intelectuais, que, na segunda metade do século vão opor os valores chamados "espirituais", baseados na ciência, na arte, na filosofia e também na religião, aos valores "corteses" da aristocracia.A seus olhos somente os primeiros são valores autênticos, profundos; os outros são superficiais e desprovidos de sinceridade.

Assim, o termo só será pensado no plural a partir da concepção alemã de cultura, entendida como os aspectos singulares de cada povo. Em especial, as idéias de Johan Gottfried Herder antecipam a noção de diversidade cultural. Em oposição aos franceses, a concepção alemã de cultura ressaltará as singularidades dos indivíduos históricos das diferentes nações, evidenciando uma outra idéia de humanidade ${ }^{16}$.

Apresentados os significados de "cultura", concluímos o seguinte: a idéia de uma humanidade "única", imbuída no conceito de civilização, sofreu justificadamente uma reação imediata que evidenciou as diferenças mais do que relevantes dos seres humanos englobados em um único conceito (o de humanidade) insensível a essa diferença ${ }^{17}$.

Além disso, cabe uma breve exposição acerca do estado atual do conceito de cultura: apesar de "cultura" e "civilização" ainda serem utilizadas de maneira equivalente (também por antropólogos) elas são, faticamente opostas- o uso de cultura acabou por se cristalizar, como "peculiaridade de cada povo", incluindo-se nesse conjunto até mesmo os outrora não civilizados

16 Nas palavras de M. Rouché,citado por Fernando Quintana (ROUCHÉ, apud QUINTANA,2002) Os clássicos franceses do século XVIII chegavam ao homem por subtração,suprimindo toda cor local ou histórica,e sua noção de homem ,na medida que era de todos os tempos e de todos os países,terminava sendo de nenhum tempo e de nenhum país,senão talvez do seu.Herder,pelo contrário(...)defende a humanidade por adição de todas as épocas e de todas as culturas nacionais,consideradas no que cada uma possui de único e de incomunicável.

\footnotetext{
17 Para Herder, citado por Eagleton (HERDER apud EAGLETON, 2003, P. 24) a cultura não significa uma narrativa grandiosa e linear da humanidade em seu todo, mas uma diversidade de formas de vida específicas, cada uma com suas leis evolutivas próprias e peculiares.
} 
(ou bárbaros), ou seja, "numa inversão curiosa, os selvagens agora soa cultos, mas os civilizados não" (EAGLETON, 2003, p. 25).

Observa-se, portanto, que a pretensa universalidade, esbarrou em uma diferença alarmante: assim, ao selvagem encontrado a época dos "descobrimentos", dificilmente poderia se chamar de "homem livre e racional, distinto da natureza", categoria, que posteriormente teve de recuar a sua abrangência anterior, no momento em que muitos homens distintos são encontrados e, sobretudo, quando a própria Europa vive com diferenças tão sugestivas, como a particularidade dos povos europeus, que dificultou inclusive a unificação de seus territórios, sendo a Alemanha um bom exemplo disso. Não seria essa uma evidência de que os seres humanos, antes de se "unificarem" sob o conceito de cultura, possuem, antes, várias naturezas?

Concluímos o presente capítulo com as palavras de Eagleton (EAGLETON, 2003 p. 11), que evidenciam efetivamente a importância do conceito de cultura par ao presente trabalho:

Se a palavra "cultura" guarda em si os resquícios de uma transição histórica de grande importância, ela também codifica várias questões filosóficas fundamentais. Neste único termo entram indistintamente em foco questões de liberdade e determinismo, o fazer e o sofrer, mudança e realidade, o dado e o criado. Se cultura significa cultivo, um cuidar que é ativo, daquilo que cresce naturalmente, o termo sugere a dialética entre o artificial e o natural, entre o que fazemos e o que o mundo nos faz.É uma noção "realista", no sentido epistemológico, já que implica a existência de uma natureza matéria- prima além de nós; mas tem também uma dimensão "construtivista", já que essa matéria-prima precisa ser elaborada numa forma tão humanamente significativa.Assim, trata-se menos de uma questão de desconstruir a oposição entre a cultura e a natureza do que reconhecer que o termo "cultura" já é uma tal desconstrução.

\subsection{A ciência e suas questões}


Os tempos modernos introduziram igualmente novas formas de expressar a relação do homem com "os outros". Nesse sentido, assistiu-se à necessidade de se instaurar modos de mediação para falar sobre a experiência humana com o ambiente, rompendo-se com a possibilidade de se considerar sua experiência ordinária que cede lugar àquela que demanda um método formal.

O conhecimento científico torna-se, por sua vez, a única forma legítima e reconhecida através da qual o homem moderno do ocidente se relaciona com o mundo natural.

A razão disso reside no fato de o desenvolvimento da ciência ao longo da modernidade conferir-Ihe o poder do discurso relativamente aos objetos, que ser quer conhecer, uma vez que sua autonomia inicial em relação ao Estado e à religião tornou-a parte de um universo dos "fatos indiscutíveis", distante do mundo dos interesses (políticos, econômicos) no qual impera a eterna discussão. O conhecimento científico é tido então como "puro" e dissociado das questões sociais, uma vez que entendido como a revelação da natureza.

A ciência estará igualmente dentro do contexto dos anseios modernos e seu advento reforçará a crença em um progresso a ser alcançado por meio das descobertas científicas, que possibilitará ao sujeito livre conhecer as leis naturais e intervir em sua história- a ciência, juntamente com a razão, teria a incumbência de salvar a humanidade do obscurantismo, talvez substituindo o lugar (rearranjo de novas crenças?) que deus ocupava na Idade Média.

Esse modo de pensar teve como efeito o aparecimento de objetos mudos que "falam" apenas aos cientistas- os cidadãos são desqualificados para tanto e só os cientistas possuem a legitimidade do discurso sobre os objetos, ou seja, dentre todos que existem e que convivem, apenas um determinado grupo tem o direito de fala ${ }^{18}$.Por sua vez,percebe-se novamente o

\footnotetext{
${ }^{18}$ Sobre essa questão, contudo, o que se percebe atualmente é a relativização da autonomia dos cientistas,pois os financiadores das pesquisas(detentores do poder econômico)acabam por ditar seus rumos. Além disso,muitas vezes um determinado é descoberto, não para ser compartilhado e sim para ser armazenado e manipulado.Como bem expõem Hardt e Negri (HADT e NEGRI,2004, p. 358) Outro tipo de luta biopolítica diz respeito ao controle do conhecimento.O conhecimento científico em tal medida tornou-se parte da produção econômica que o paradigma econômico dominante deslocou-se da produção de bem materiais para a produção da própria vida.Se o conhecimento se torna tão identificado com a produção, não deve surpreender que as potências econômicas apliquem suas marcas às manifestações do conhecimento e submetam a produção do conhecimento às regras do lucro.
} 
aparecimento da divisão natureza/cultura,opondo os objetos naturais(fatos) aos valores,inerentes à cultura às questões sociais.

O problema de tal concepção reside no fato de não aceitar outros discursos, que evidentemente estão inscritos em esferas distintas. Como destaca Deleuze (DELEUZE, 1976, P. 20): "E por que é que não hei de inventar um discurso sobre qualquer coisa, ainda que esse discurso seja completamente irreal e artificial sem que me perguntem com que direito o faço? (...) o argumento da experiência reservada é um mau argumento reacionário"

O enunciado de um cidadão não será igual ao de um cientista, mas não pode ser subestimado, quando o que se coloca em questão é a necessidade de uma melhor gestão da vida em comum.

A autonomia da ciência no século XVII, relativamente ao Estado e à religião mostrou-se emancipadora. Contudo, a associação da ciência com a técnica e o uso do conhecimento científico nas empresas acabou tendo como efeito o estabelecimento de uma relação de dominação do homem com a natureza- da ciência nascente, marginal, contestadora e anunciante de um novo tempo, passou-se à ciência intimidadora. ${ }^{19}$

Tudo isso comprova o fetiche que a ciência, sendo quase uma nova religião ou um novo demônio, exerce sobre o imaginário coletivo, o que necessita ser repensado. ${ }^{20}$

Entretanto, entende-se que a ciência, como a forma moderna e legítima de falar sobre a natureza, deve ser não apenas repensada, como também relativizada, na medida em que se apresenta como apenas uma forma (dentre tantas outras existentes) que o homem moderno encontrou de se relacionar com tudo aquilo que não é humano - é necessário que se atente para

\footnotetext{
19 Entende-se que a "intimidação" que a ciência acaba por exercer nos dias atuais diz respeito a sua inserção nas dinâmicas econômicas e políticas, o que é inevitável, uma vez que a pureza outrora desejada simplesmente não existeo que pode ter ocorrido no passado é um grau de ingerência menor dos outros atores, relativamente aos cientistas e ao conhecimento científico. Nesse sentido,percebe-se que a ciência não é só intimidadora,mas também intimidada.Muito além dos enunciados científicos despóticos,que fazem calar os cidadão,no interior da consolidação das descobertas científicas existem inúmeras discussões e, em última análise, o consenso,que assim como nas assembléias políticas, é necessário.Para mais detalhes sobre a dinâmica das ciências, ver MORIN,2008

${ }^{20}$ Como bem afirma Bruno Latour (LATOUR, 2004, p. 63): "Se a naturalização desempenhou um papel tão importante na luta anti-religiosa,é porque sempre utilizou o objeto da natureza,o objeto causal,o objeto natural,limpo,o objeto raspado,o objeto sem risco,como um aríete para forçar a porta dos poderes do osbcurantismo. A natureza permanece impregnada inda da religião que ela combateu."
} 
esse fato, sobretudo para que não se perca a dimensão dos efeitos das práticas científicas e de sua impossibilidade frente a diversas questões contemporâneas, que evidenciam o quanto os fenômenos da natureza são também questões sociais, pois a natureza, tal como a entendemos está condicionada ao desígnios da sociedade.

Nesse sentido, muito elucidativa é análise feita por Bruno Latour (um dos autores de referência do presente trabalho) acerca da questão: a divisão "humanos" e não"humanos". O autor entende que a representação de social, advinda da separação natureza/ cultura, acaba por imobilizar os seres humanos na prisão social, que está completamente separada das "coisas em si "e, por um grande mistério, os sábios, permanecem capazes de romper com a sociedade e atingir a objetividade, decorrente da análise do mundo natural ${ }^{21}$.

A crítica a tal forma de organização social reside no fato de que essa não permite a devida gestão do mundo comum- sobretudo, porque há uma grande impossibilidade de escuta e de discurso, seja para os objetos mudos, que apenas falam aos cientistas, seja aos sujeitos (humanos), prisioneiros, do social, que não podem estabelecer qualquer relação com os objetos que lhes dê legitimidade para falar sobre eles, tarefa atribuída de maneira reservada aos cientistas. ${ }^{22}$

Todavia, o autor pretende escapar da escolha "realidade social" versus "as coisas em si", pois "uma tal armadilha não pode levar senão à única condição de que ninguém examine, ao mesmo tempo a idéia de Ciência e a de sociedade, que ninguém duvide simultaneamente, da epistemologia e da sociologia". (LATOUR, 2004, p. 37). Nesse sentido, a proposta de Latour não é "tomar lugar no debate que vai permitir mensurar a parte respectiva da natureza e da sociedade nas representações que nós possuímos, mas de modificar a concepção do mundo social e político que serve de evidência as ciências sociais e as ciências naturais". (LATOUR, 2004,p. 68).

\footnotetext{
${ }^{21} \mathrm{O}$ autor entende que a Ciência com " $\mathrm{C}$ " maiúsculo é a politização das ciências pela epistemologia, com o intuito de tornar impotente a via política ordinária, fazendo pesar sobre ela a ameaça de uma natureza indiscutível (LATOUR, 2004, p. 26)- a ciência seria, nesse sentido, a única salvação contra o “inferno social”

${ }^{22}$ Ainda que o mundo da verdade difira absolutamente e não relativamente do mundo social o Sábio pode, apesar de tudo, ir e voltar de um ao outro mundo: a passagem, fechada para todos os outros, está aberta somente a ele.

(LATOUR, 2004, página 28)
} 
O autor, por sua vez, acaba por afirmar a existência de uma objetividade, aproximando-se, assim, do realismo científico, mas concebe essa realidade exterior em outros termos. Em suas palavras: "sim, há uma realidade exterior objetiva, mas essa exterioridade não é definitiva e assinala simplesmente que novos não humanos, jamais incluídos no trabalho do coletivo, se encontram mobilizados, recrutados, socializados" (LATOUR, 2004, página 74) .

A proposta de Bruno Latour é no sentido do estabelecimento de uma nova forma de organização da vida pública, que inclua humanos e não humanos de maneira democrática- assim, os representantes de ambos devem ser sempre vistos de forma duvidosa, com vistas a permitir o consenso que mais exprima a necessidade do coletivo ${ }^{23}$. O autor, todavia está longe de propor uma forma de organização baseada única e exclusivamente na interpretação individual da natureza, como se pode observar no trecho seguinte:

Pode-se laicizar as ciências como se laicizou a religião, e fazer do conhecimento exato uma opinião, certamente respeitável, mas privada?Devemos imaginar um Estado que não assegurasse nada além da liberdade de exercer livremente os cultos eruditos, mas sem sustentar nenhum?Assim formulada, a solução parece aberrante, pois chegou-s a laicizar a moral e a religião, unicamente graças a esta garantia de uma unidade já feita, que a Ciência apresentava numa bandeja.Agnóstica em matéria de religião, como de Ciência, a República laica seria esvaziada de qualquer substância. Em questão de mundo comum, ela repousaria sobre o mais desinteressante e o mais arbitrário dos pequenos denominadores: o rei- eu. (LATOUR, 2004, p. 361)

O engenhoso sistema de Bruno Latour ${ }^{24}$, com seus inúmeros procedimentos, para o devido funcionamento da assembléia de deliberação do coletivo não faz parte do objeto preciso do presente trabalho.

Todavia, o teor de sua crítica aqui exposta intencionou ao menos sofisticar o debate, para livrá-lo de todas as armadilhas previsíveis da crítica, quando se faz alguma objeção à legitimidade do discurso científico. Nesse sentido, entende-se necessário que a crítica a esse discurso esteja muito bem localizada, ao menos na indicação de suas premissas e aqui era mais do que necessário

\footnotetext{
${ }^{23} \mathrm{O}$ conceito de coletivo é assim definido por Bruno Latour: "distingue-se em primeiro lugar de sociedade, termo que nos remete a uma má distribuição de poderes; acumula em seguida os antigos poderes da natureza e da sociedade num só lugar antes de se diferenciar novamente em poderes vários (consideração, organização, acompanhamento). Embora empregado no singular, o termo não nos remete a uma unidade já feita, mas a um procedimento para coligar as associações de humanos e não humanos. (LATOUR, 2004, p. 372-373)
} 
uma crítica a todo discurso que pretenda ser a última palavra sobre a "ontologia das coisas", sem, contudo, sugerir qualquer caminho ao niilismo e anarquia. Entende-se, antes, que o consenso é necessário, mas também que os termos nos quais esse consenso (sobre a natureza e sobre a sociedade) se produz devem estar em discussão permanente.

\subsection{Sugestão da Antropologia: Meio Ambiente e Antropocentrismo.}

Esta parte da monografia se dedica a expor a relação que os índios da Amazônia estabelecem com os "outros" e foi extraída de uma pesquisa antropológica, que se percebe útil para relativizar a "naturalização" que foi feita da relação que os modernos ocidentais estabeleceram com a natureza.

Como pensam os índios?De forma muito distinta dos modernos: índios vêem os animais como humanos- para eles, não há uma distinção entre os humanos e os não humanos, tal como se entende a condição humana a partir da Modernidade.Essa condição, por sua vez, seria caracterizada por uma determinada posição que todos os seres,independente de sua forma, podem assumir.Através do xamanismo, espécie de ritual indígena, certos indivíduos "humanos", são capazes de romper o obstáculo de sua forma e adotar o ponto de vista de "sujeitos" que possuem a forma distinta deles. Nas palavras de Eduardo Viveiros de Castro (VIVEIROS DE CASTRO, 2002,p. 358):

O xamanismo amazônico pode ser definido como a habilidade manifesta por certos indivíduos de cruzar deliberadamente as barreiras corporais e adotar a perspectiva de subjetividades aloespecíficas, de modo a administrar as relações entre essas e os humanos. Vendo os seres humanos como este se vêem (como humanos), os xamãs são capazes de assumir o papel de interlocutores ativos no diálogo transespecífico; sobretudo, eles são capazes de voltar para contar a história, algo que dificilmente os leigos conseguem fazer.O encontro ou intercâmbio de perspectivas é um processo perigoso e uma arte política- uma diplomacia.

\footnotetext{
${ }^{24}$ Para maiores detalhes, ver Políticas da Natureza: como fazer ciência na democracia, livro em que Bruno Latour irá expor como é possível uma outra associação entre humanos e não humanos.
} 
A observância desse ritual evidencia algumas questões relativas à diferença de forma de conhecimento, relativamente à epistemologia ocidental, que é afirmada por meio dessa práticapara nós, conhecer é objetivar, retirando do objeto que se quer conhecer qualquer vestígio de subjetividade-Como afirma Robert Blanché,citado por Fernando Fagundes Ribeiro (BLANCHÉ apud RIBEIRO,2007, p. 38) :

O objeto é definido pelo processo de objetivação do saber; ele cessa de ser posto previamente a todo conhecimento,como uma coisa(...)o trabalho de objetivação não é senão a outra face do processo de dessubjetivação.

Por sua vez, na perspectiva ameríndia a prática do conhecimento se transforma em uma prática oposta, conhecendo-se algo apenas partir da personificação desse "objeto", -a humanidade é então entendida não mais como forma e sim como condição- a condição de sujeito.Novamente, Eduardo Viveiros de Castro (VIVEIROS DE CASTRO, 2003,p. 358) explica:

O xamanismo é um modo de agir que implica um modo de conhecer, ou antes, um certo ideal de conhecimento.Tal ideal é, sob vários aspectos, o oposto polar da epistemologia objetivista favorecida pela modernidade ocidental.Nesta última, a categoria do objeto fornece o telos: conhecer é objetivar; é poder distinguir no objeto o que lhe é intrínseco do que pertence ao sujeito cognoscente, e que, como tal, foi indevida e /ou inevitavelmente projetado no objeto.Conhecer assim é dessubjetivar, explicitar a parte do sujeito presente no objeto, de modo a reduzi-la a um mínimo ideal.Os sujeitos, tanto quanto os objetos são vistos como resultantes de processos de objetivação: o sujeito se constitui ou reconhece a si mesmo nos objetos que produz, e se conhece objetivamente quando consegue se ver "de fora' com um "isso". Nosso jogo epistemológico se chama objetivação; o que não foi objetivado permanece irreal e abstrato.A forma do Outro é a coisa.

Observa-se que essa visão da cultura ameríndia atribui aos animais a capacidade de possuir uma intenção,bem como um ponto de vista,o que os permite ocuparem a posição de sujeito. Por meio dessa perspectiva, os conceitos de cultura e de natureza são vistos a partir de outra relação, sendo a cultura "a natureza do sujeito", o meio pelo qual todo agente é capaz de expressar sua natureza constitutiva.

Certamente, para aqueles que se afirmam sujeitos, donos da história e únicos capazes de ter lugar ativo no discurso sobre si e sobre os outros (ainda que obedecendo a determinados métodos formais), atribuir a possibilidade de fala aos outros pode parecer impensável, além das possíveis dificuldades de comunicação. 
Como falar com os outros?Quais são os diálogos possíveis?Certamente não existe uma resposta mas um caminho a ser descoberto,pois: " as aparências enganam porque nunca se pode estar certo sobre o ponto de vista dominante,isto é, que mundo está em vigor quando se interage com outrem.Tudo é perigoso, sobretudo quando tudo é gente e talvez nós não o sejamos"(VIVEIROS DE CASTRO, 2003, p. 397)

Assim pensam os ameríndios. Contudo, antes que se pense em um "devir ameríndio", é preciso refletir acerca do fato de que os modernos ocidentais são outros. O relato antropológico apenas serviu para que nos estranhemos um pouco. Como bem disse Herder, citado por Eagleton (EAGLETON, 2003, p. 24) “O que certa nação julga indispensável para os círculos de seus pensamentos nunca entrou na mente de uma outra,e por outra foi julgado ultrajante". Mas vale a ressalva de Eduardo Viveiros de Castro:

(...) se os índios têm razão, então a diferença entre os dois pontos de vista não é uma questão cultural, e muito menos de mentalidade. Se os contrastes entre relativismo e perspectivismo ou entre multiculturalismo e multinaturalismo forem lidos à luz, não de nosso relativismo multicultural, mas da doutrina indígena, é forçoso concluir que a reciprocidade de perspectivas se aplica a ela mesma, e que a diferença é de mundo, não de pensamento(VIVEIROS DE CASTRO, 2003, p. 399$)^{25}$

\subsection{A Modernidade e o Positivismo Jurídico}

Nessa parte do trabalho serão analisadas as conexões do Direito com o paradigma hegemônico, em suas aproximações e afastamentos.

Em um primeiro momento será analisada a influência do paradigma dominante do ponto de vista da Teoria do Direito, ou seja, como o referido paradigma influenciou no "método" de conhecimento do Direito.

Posteriormente, a análise se ocupará das conseqüências "práticas" da concepção hegemônica dentro do fenômeno jurídico, no sentido de atentar para a aplicação do Direito frente

\footnotetext{
${ }^{25}$ Aqui o autor complementa sua conclusão com uma importante citação de Lévi- Strauss: Talvez venhamos a descobrir, um dia, que a mesma lógica opera no pensamento mítico e no pensamento científico,e que o homem sempre pensou igualmente bem.O progresso- se é que o termo poderia então se aplicar- não tivera portanto consciência por teatro, mas o mundo onde a humanidade dotada de faculdades constantes encontra-se, no decorrer de sua longa história, continuamente às voltas com novos objetos (STRAUSS, apud VIVEIROS DE CASTRO, p. 399)
} 
a situações decorrentes desse modo de pensamento- esse sentido, o Direito Ambiental surge como a resposta "prática" do direito à necessidade de regulamentação das relações entre homem e o meio ambiente.

Antes de se analisarem as premissas kelsenianas per se (no que essas premissas elucidam acerca da divisão natureza e cultura, como proposto), deve-se traçar um breve panorama acerca das idéias constituintes do positivismo jurídico. Novamente, deve-se retomar a Modernidade como evento essencial para a compreensão do surgimento de novas concepções epistemológicas que viabilizarão em momento posterior a emergência do positivismo jurídico.

A forma de organização política na Modernidade é o Estado, que se fortalece frente às ruínas do regime feudal, tornando-se o único ente detentor do exercício legítimo da força, bem como de toda e qualquer regulamentação das relações sociais (através do Direito), sobrepondo-se aos métodos de resolução de conflitos, que antes (na Idade Média), limitavam-se às singularidades de cada feudo ${ }^{26}$.

Dessa forma, o regulamento das relações sociais se estendia aos limites territoriais do Estado, evidenciando a importância do instrumento capaz de institucionalizar as relações sociais em grande escala- a norma jurídica. ${ }^{27}$

Haverá, nesse sentido, enorme preocupação acerca das condições de produção dessas normas, bem como de suas possibilidades e de seus impasses, sobretudo no que diz respeito ao seu estudo.

Assim, a inovação acerca do estabelecimento de parâmetros a serem observados quando da criação dessas normas logo irá surgir para por fim aos conflitos (materializados nas guerras civis)

\footnotetext{
${ }^{26}$ Nas palavras de Quentin Skinner: Mais um pré- requisito para se chegar ao moderno conceito de Estado é que se reconheça que a suprema autoridade em cada regnum independente, enquanto poder legislativo e objeto de lealdade, não conte com rivais no interior de seu território. Uma tal imagem unitária da soberania política não teve condições de emergir, na Europa medieval, devido às teses jurídicas que fundamentavam a organização feudal da sociedade e à exigência da Igreja no sentido de atuar como um poder legislativo que coexistisse com as autoridades seculares, em vez de subordinar-se a elas.(SKINNER, 1996, p. 617)

27 Importante observar que apenas no âmbito dessa estabilidade social e política, a ciência será capaz de se desenvolver, pois como bem assevera Michel Serres: "antes do consenso científico sobre a exatidão do recorte ou a necessidade da demonstração, impõe-se um contrato jurídico, fazendo com que em primeiro lugar os interessados entrem em acordo (SERRES, 1992, p.68)
} 
tanto mais o meio utilizado por ele para manter a segurança deverá estar revestido da certeza mais apaziguadora de conflitos. Entretanto, a demanda descrita surgirá em resposta ao avanço dos excessos (questionamentos políticos e sociais) que não tardavam a estarem inseridos nas teorias jurídicas.

Pode-se, então, compreender a emergência do Positivismo Jurídico a partir da supremacia das normas, uma vez, que essa corrente doutrinária apenas considera como Direito, o que é posto pela autoridade competente. Nesse sentido, bem expõe Bobbio (BOBBIO, 1999,p. 119-120) acerca da relação entre Positivismo Jurídico e formação do Estado Moderno aqui exposta:

(...) o Positivismo Jurídico nasce do impulso histórico para a legislação, se realiza quando a lei se torna a fonte exclusiva- ou de qualquer modo absolutamente prevalente- do direito- e seu resultado último é representado pela codificação (...) o impulso histórico para a legislação nasce da dupla exigência de pôr ordem no caos do direito primitivo e de fornecer ao Estado um instrumento eficaz para a intervenção na vida social.

O impulso para a legislação não é um fato limitado e contingente, mas um movimento histórico universal e irreversível, indissoluvelmente ligado à formação do Estado do Estado Moderno.

Ainda, Norberto Bobbio (BOBBIO,1999, p. 120) nos dá importante lição acerca do significado histórico do positivismo jurídico, que vai ao encontro da proposta do presente trabalho. Em suas palavras:

O dar prevalência à lei como fonte do direito nasce do propósito do homem de modificar a sociedade. Como o homem pode controlar a natureza através do conhecimento de suas leis, assim ele pode transformar a sociedade através da renovação das leis que a regem; mas para que isto seja possível, para que o direito possa modificar as estruturas sociais, é mister que seja posto conscientemente segundo uma finalidade racional; é mister que seja posto através da lei.

Exposta a parte histórica, deve-se atentar para uma importante advertência: o Positivismo Jurídico não deve ser associado ao Positivismo comteano. ${ }^{28}$ Além disso, o positivismo jurídico não

\footnotetext{
${ }^{28} \mathrm{O}$ termo positivismo vincula-se a distintos movimentos nas humanidades, desde o positivismo filosófico de Augusto Comte, muito relevante por sua ênfase na observação e no rigor teórico, até o positivismo lógico do Circulo de Viena. Se as correntes possuem alguma semelhança, essa não é central em nenhuma das três linhagens. O positivismo jurídico, por exemplo, não tem em seus homônimos fonte importante de inspiração.
} 
se apresenta de forma única ${ }^{29}$, comportando inúmeros autores e, conseqüentemente, pontos de vista distintos sobre o Direito.

Intentou-se, no presente capítulo, expor as idéias gerais que se apresentam como condições para a devida compreensão do capítulo seguinte, que se irá se ater a forma como Kelsen partirá da divisão natureza/sociedade nas bases de sua teoria "pura" do Direito.

\subsection{Kelsen e o "paradigma dominante" no Direito}

Kelsen é um dos primeiros autores a quem os estudantes de direito são apresentados, mas, na maioria das vezes, coloca-se como um enigma, ou, quem sabe, como "o óbvio que não faz sentido"- sua proposta, a de fazer do direito uma "ciência", livre de qualquer influência política e ideológica foi também sua opção de vida, como se pode observar do trecho abaixo(LIMA, C.E,1995):

Kelsen era agnóstico em matéria de religião e indiferente a nacionalidade.Sempre procurou manterse alheio a qualquer espécie de vinculação político partidária.Não se filiou ao Partido Social Democrata porque, além de repudiar a teoria política marxista, entendia que como professorpesquisador deveria resguardar ao máximo sua independência científica, livre de qualquer engajamento político.

Em momento posterior, esses mesmos estudantes continuam a ouvir inúmeras críticas contra a teoria kelseniana e, assim, os outrora futuros "operadores" da "ciência jurídica", enchemse de perplexidade ou de idéias tão distorcidas sobre o referido autor que melhor seria jamais terem ouvido qualquer enunciado a seu respeito- após momentos de regozijo e onipotência, apresenta-se a triste notícia de que a norma fundamental, “o núcleo de lá onde o direito positivo toca o seu abismo" (LIMA, 1995, p. 4) não é nada mais do que uma crença.

Portanto, discorrer acerca de Kelsen é, antes de qualquer coisa, um grande desafio- Kelsen encerra em si um autor, uma obra e uma infinidade de controvérsias, além, é claro, de um enorme senso comum jurídico.

\footnotetext{
${ }^{29}$ Aqui novamente nos ensina Norberto Bobbio: “Ora, sustentamos que para poder fazer um balanço do positivismo jurídico, para poder estabelecer aquilo que dele deve ser conservado e o que deve ser abandonado ou, como se diz habitualmente quanto às doutrinas, verificar o que está vivo e o que está morto, é necessário não considerar esse movimento como um bloco monolítico, mas distinguir nele alguns aspectos fundamentalmente diferente. (BOBBIO, 1999, p. 233)
} 
Inicia-se o presente capítulo com uma citação extraída do prefácio à primeira edição da obra "Teoria Pura do Direito", em que o autor irá demonstrar a diversidade de repercussões dessa obra. Sobre a Teoria Pura do Direito:

Os fascistas declaram-na liberalismo democrático, os democratas liberais ou os sociais-democratas consideram-na um posto avançado do fascismo. Do lado comunista é desclassificada como ideologia de um stalinismo capitalista, do lado capitalista-nacionalista é desqualificada, já como bolchevismo crasso, já como anarquismo velado. O seu espírito é- asseguram muitos- aparentado com o da escolástica católica;ao passo que outros crêem reconhecer nela as características distintivas de uma teoria protestante do Estado e do Direito. E não falta também quem a pretenda estigmatizar com a marca do ateísta. Em suma, não há qualquer orientação política de que a Teoria Pura do Direito não seja suspeita. (KELSEN, 2003,p. XII)

Torna-se, pois evidente, de início, a impossibilidade de construção de uma teoria "pura", que não desperte os ânimos das mais distintas orientações ideológicas. Ainda que se desconfie que Kesen possuísse pretensões bem menos audaciosas do que aquelas apresentadas pelas críticas acima expostas, percebe-se que seu pensamento não ficou imune a capacidade cognitiva, nada "pura" ou "imparcial" dos seres humanos.

O presente capítulo intenciona expor de forma pontual um aspecto acerca da obra de Kelsen: o posicionamento desse autor acerca da divisão natureza e cultura, tudo para evidenciar em que termos esse autor foi influenciado pelo "paradigma dominante", cujo panorama já foi anteriormente traçado.

Parte-se, então para a análise das "impressões" de Kelsen acerca da dicotomia natureza/cultura, bem como da referida divisão enquanto pressuposto para a teoria kelseniana do direito.

De início, certo "dado histórico" é fundamental para o devido entendimento da teoria kelseniana: o surgimento das ciências sociais e a extensão do paradigma dominante das ciências naturais aos estudos sociais.

O método científico emergente no século XVI foi estendido aos estudos da sociedade datados do século XIX, com destaque para o surgimento de duas formas identificadas por Boaventura Souza Santos (SANTOS, 2003, p.33), que propõe termos distintos nos quais a referida extensão ocorrerá.

Assim, uma primeira concepção entende pela aplicação total e irrestrita do modelo de 
conhecimento inicialmente pensado para as ciências naturais nas ciências sociais e ainda que admita a complexidade dos fenômenos sociais ( em relação aos fenômenos naturais) não abdica de uma uniformidade metodológica para ambos, pois "por maiores que sejam as diferenças entre os fenômenos naturais e os fenômenos sociais é sempre possível estudar os últimos como se fossem os primeiros (SANTOS, 2003, p.34)

A segunda vertente, por sua vez, entende que a transposição do modelo das ciências naturais para as ciências sociais é irrealizável, tendo em vista a impossibilidade de o cientista social despir-se de seu olhar subjetivo quando da análise dos fenômenos sociais. Assim, reivindica para as ciências sociais "um estatuto metodológico próprio" (SANTOS, 2003, p. 38), mas igualmente parte da divisão natureza/ cultura para realizar sua análise, sendo, nesse sentido, ainda herdeira do paradigma dominante, pois considera os seres humanos como distintos dos demais seres encontrados na natureza.

Retornando ao pensamento de Kelsen, o mesmo autor partirá da segunda corrente descrita, marcando inicialmente a diferença entre as ciências naturais e o direito, sem, contudo renunciar ao projeto de construir uma ciência do direito, cujo objeto é a norma jurídica, livre de toda e qualquer influência subjetiva de seu observador.

Inicialmente Kelsen deve retirar da "ciência do direito" toda e qualquer influência política. Assim:

A despolitização que a teoria pura do direito exige se refere à ciência do direito, não ao seu objeto, o direito.O direito não pode ser separado da política, pois é essencialmente um instrumento da política.Tanto sua criação como sua aplicação são políticas, é dizer, funções determinadas por juízos de valor.Porém, a ciência do direito pode e deve ser separada da política, se é que se pretende valer como ciência. (KELSEN, apud SGARBI, 2007, p.2)

Observa-se, então, a existência de duas ordens distintas no Direito: a ordem prática, de um lado, e a ordem epistemológica, de outro- é sobre essa segunda ordem que incidirá a defesa kelseniana de uma pureza metodológica, para que o direito adquira o status de ciência.

Nesse sentido, o modelo de ciência para Kelsen seria o modelo das ciências naturais, no que esse modelo é capaz de expressar, enquanto conhecimento seguro e previsível. Importante destacar que a "opção" pelo modelo das ciências baseia-se no pressuposto de que apenas essas seriam isentas de toda metafísica que por séculos predominou na explicação dos fenômenos 
naturais.

Dessa forma, Kelsen entende que o homem dos tempos primitivos não era capaz de entender os acontecimentos do "mundo natural" senão sob a ótica de suas relações sociais, ou seja, esses fenômenos jamais teriam uma causa própria, objetiva e que em nada se relacionava com os afetos e crenças humanas. Em suas palavras, "não há razão que faça supor entre os homens primitivos uma tendência acentuada à cognição ou um desejo direto de uma explicação objetiva do mundo, é dizer, uma explicação independente de seus desejos ou temores e livre de toda valoração" (KELSEN apud SGARBI, 2007, p. 62) e "a relação do homem primitivo se baseia não sobre a idéia de uma conexão objetiva dos fatos, isto é, sobre a suposição de um nexo causal produzido por forças impessoais, senão sobre a idéia de uma conexão entre duas pessoas, sobre a suposição de uma relação social" (KELSEN apud SGARBI, 2007, p.62).

Para Kelsen, o método das ciências naturais foi fundamental para a emancipação humana de seus afetos na explicação dos fenômenos naturais, uma vez que estabelece um método objetivo para a devida intelecção desses fenômenos e liberta o homem das explicações míticas outrora hegemônicas.

Tal concepção, por sua vez, fundamenta a crítica kelseniana a doutrina do direito natural, pois essa afirmava a existência de valores absolutos, não verificáveis do ponto de vista científico e que, em última análise, tendem a tornar absoluto o que é relativo, a exemplo da justiça, que jamais encerrará em si um conceito objetivo e independente dos valores de cada indivíduo ${ }^{30}$

30 - Como bem pontua Adrian Sgarbi “(...) o caráter do direito natural- invocação e justificativa para o comportamento humano que determina o que é justo e o que não é - é desprestigiado por Kelsen, dentre outras razões, pelo fato de os teóricos do direito natural afirmarem que existe um regulação absolutamente justa para as relações humanas, seja mediante o uso de uma pretensa natureza, seja encontrando referencial de eleição a própria natureza do homem como ser dotado de razão. Observando esses critérios de determinação do justo, ou se supõe haver um Deus ou deuses por detrás dessa natureza, sendo o direito natural expressão de Sua vontade ou vontades, ou, ainda se considera que a natureza em si possui uma vontade e inteligência finalista que o homem consegue ,com o uso de sua razão, alcançar.A natureza - nos sentidos aqui contemplados resultaria, portanto, numa espécie de autoridade suprema à qual o homem deve obediência, um ser sobre - humano conformador dos seus atos e ciente de suas necessidades existenciais. Mas essas fundamentações, afirma Kelsen, encerram um sofisma: com essa vontade chega-se á conclusão de que alguém precisa ser porta voz dessa vontade.( SGARBI, 2007, p. 18,79).Nesse ponto, cabe a seguinte observação: a idéia de um fundamento último para o bem e para o mal, nos termos da doutrina justanuralista, acaretará em um absolutismo filosófico, presente em governos autoritários, que possuem sempre um soberano para colocar os termos do bem e do mal. Kelsen, por sua vez, seria adepto do relativismo filosófico, posição que entende pela relatividade dos valores, ou seja, " a opinião que existe somente valores relativos, e, pois, somente 
Passa-se à distinção feita por Kelsen entre as ciências naturais e o Direito, fundamental para a compreensão dos termos nos quais a ciência jurídica será possível, pois, apesar de o modelo de ciência para o referido autor ser o modelo das ciências naturais, a ciência jurídica, enquanto ciência social é regida pelo princípio da imputação, distinto daquele que rege as relações da natureza (princípio da causalidade). Nas palavras de Kelsen: "Se há uma ciência social que é diferente da ciência natural, ela deve descrever seu objeto segundo um princípio diferente do da causalidade. Como objeto de uma tal ciência que é diferente da ciência natural, a sociedade é uma ordem normativa de conduta humana."

Nesse ponto, cabe uma ressalva: Kelsen entende que alguns ramos das ciências sociais operam sob o princípio da causalidade, tais como a psicologia e a sociologia. Assim, a conduta humana, considerada em seu todo não está reduzida nem ao princípio da causalidade, nem ao princípio da imputação, sendo constituída por ambos. Esse segundo, princípio, por sua vez, apenas se revela sob o pressuposto de que a conduta humana encerra em si um domínio normativo. ${ }^{31}$ Assim, igualmente, o Direito deverá ser considerado enquanto ciência, pois toda e qualquer explicação causal acerca do fenômeno jurídico será antes, sociologia jurídica, psicologia jurídica, mas nunca ciência do Direito ${ }^{32}$.

Feita a ressalva, deve-se passar às definições acerca do princípio da causalidade e da imputação. O primeiro é entendido como o princípio observado na natureza, cujos elementos

verdades relativas e que, portanto, cada valor e cada verdade- a par do indivíduo que os procura- devem estar sempre preparados para deixar o campo e a deixar substituir.(KELSEN apud SGARBI, 2007, p. 82). Nesse sentido, a democracia seria a forma de governo mais sensível à existência de valores relativos, e, portanto, melhor para determinar as regras de convivências entre os indivíduos.

${ }^{31}$ Somente quando a sociedade é entendida como uma ordem normativa da conduta dos homens entre si é que ela pode ser concebida como um objeto diferente da ordem causal da natureza, só então é que a ciência social pode ser contraposta à ciência natural. Somente na medida em que o Direito for uma ordem normativa da conduta dos homens entre si pode ele, como fenômeno social, ser distinguido da natureza, e pode a ciência jurídica, como ciência social, ser separada da ciência da natureza. (KELSEN, p. 86)

${ }^{32}$ Uma vez conhecido o princípio da causalidade, ele torna-se também aplicável à conduta.A Psicologia a Etnologia a História, a Sociologia são ciências que têm por objeto a conduta humana na medida em que ela é determinada através de leis causais, isto é, na medida em que se processa no domínio da natureza ou da realidade natural (KELSEN,2003,p.95) 
estão ligados entre si por relações de causa e efeito ${ }^{33}$. Já o principio da imputação pode ser definido como "relação de condição e conseqüência atribuída pelo homem, quando há a descrição de uma relação específica estabelecida entre dois fatos diferenciados dos acontecimentos causais, em virtude de ser essa relação alheia aos fatos que descreve." (SGARBI, 2007, p.7)

Kelsen diferencia o princípio da causalidade do princípio da imputação sob os seguintes aspectos: primeiro, a forma de ligação dos princípios é distinta, pois enquanto o princípio da causalidade opera no plano do ser, o princípio da imputação, por sua vez opera no plano do dever ser. Assim, "o princípio da causalidade afirma que, quando A é, B também é (ou será), já no princípio da imputação" quando A é, B deve ser" (Kelsen,2003, p.100) , o que marca uma distinção do ponto de vista da "natureza" do efeito em cada caso- enquanto no princípio causal o efeito é decorrência direta dessa, no princípio da imputação, o efeito decorre de uma norma jurídica.

A segunda distinção as ser feita entre os referidos princípios diz respeito à cadeia de relações deles decorrente: se no princípio da causalidade, a cadeia de relações de causa e efeito é infinita (pois não há uma causa primeira), no caso do princípio da imputação, a cadeia causal é limitada, pois o pressuposto de uma norma jurídica não é atribuível a uma série de pressupostos ao infinito e, no caso, da teoria kesleinana, o fundamento último do princípio da imputação é a norma fundamental.

Aqui há outro destaque a ser feito: considerando-se a distinção entre os referidos princípios, pode-se questionar acerca do fundamento da existência do princípio da imputação nas condutas humanas- alguns pensarão que a justificativa para o princípio da imputação na vivência entre os homens se daria devido ao fato de os serem humanos serem racionais e dotados de vontade própria, não submetidos às leis de causalidades que regem a natureza e, por isso, capazes de instituir para si mecanismos normativos de convivência em sociedade.

\footnotetext{
33 Kelsen entende que houve uma "evolução" ao longo da história da humanidade, que permitiu o abandono, pelos seres humanos da observação dos fenômenos naturais a partir do princípio da imputação, que foi substituído pelo princípio da causalidade. Em suas palavras: O passo decisivo de uma interpretação normativa para uma interpretação causal da natureza, do princípio da imputação para o princípio da causalidade, reside no fato de o homem se tornar consciente de que as relações entre as coisas- diferentemente da relação entre os homens- são determinadas independentemente da vontade humana ou supra- humana ou, o que vem a dar no mesmo não são determinadas por normas, de que o comportamento das coisas não é prescrito ou permitido por qualquer autoridade. (KELSEN, 2003, p. 95)
} 
Kelsen, todavia, vai de encontro a esse pensamento afirmando a existência do princípio da causalidade nas relações humanas. Em suas palavras:

A instituição de uma ordem normativa reguladora da conduta dos indivíduos- com base na qual somente pode ter lugar a imputação- pressupõe exatamente que a vontade dos indivíduos cuja conduta se regula seja causalmente determinável e, portanto, não seja livre(...) Só através do fato de a ordem normativa se inserir , como conteúdo das representações dos indivíduos cuja conduta ela regula, no processo causal, no fluxo de causas e efeitos, é que esta ordem preenche a sua função social.E também só com base numa tal ordem normativa, que pressupõe a sua causalidade relativamente à vontade do indivíduo que lhe está submetido, é que a imputação pode ter lugar (KELSEN, 2003, p. 105).

Após a análise da diferenciação elaborada por Kelsen, resta o seguinte questionamento: tendo em vista a diferença entre as ciências da natureza e o Direto, como considerar o segundo ciência?

Nesse ponto, alguns irão considerar a teoria kelseniana fruto da ideologia, uma vez que o conhecimento do direito, nos moldes científicos, apenas seria possível de acordo com sua explicação causal, ou seja, como sociologia jurídica e, nesse sentido, a pretensão de uma ciência jurídica que se propõe a descrever o direito a partir do princípio da imputação não seria propriamente científica.

Kelsen responderá a essa crítica, da seguinte forma:

Somente quando se entenda ideologia como oposição a realidade dos fatos da ordem do ser, isto é, quando por ideologia se entenda tudo que não seja realidade determinada por lei causal ou uma descrição desta realidade, é que o Direito, como norma- isto é como sentido de atos da ordem do ser causalmente determinados, mas diferentes destes atos -é uma ideologia.(KELSEN, 2003, p. 117).

Todavia, Kelsen não deixará de expor em que termos sua proposta acerca do estudo do Direito é científica- para o autor, a ciência jurídica propõe um conhecimento ordenador e unitário de seu objeto - a norma jurídica - isentando-o de contradições, a exemplo do que as ciências naturais realizam em sua abordagem dos fenômenos; apresenta-se como uma descrição de seu objeto em uma perspectiva alheia aos valores e define as normas jurídicas remetendo-as à lei que Ihes serve de fundamento, assim como as ciências da natureza descrevem a experiência com remissão a uma lei dita "natural". A partir dessas explicações, Kelsen, em sua defesa de sua teoria pura, pondera (KELSEN,2003, p. 119):

Se por ideologia se entende porém não tudo que não é realidade natural, ou sua descrição, mas uma representação não-objetiva, influenciada por juízos de valor subjetivos, que encobre, 
obscurece ou desfoca o objeto do conhecimento e se designa por "realidade", não apenas a realidade natural como objeto da ciência da natureza, mas todo objeto do conhecimento e portanto também o objeto da ciência jurídica, o direito positivo como realidade jurídica, então também uma representação do direito positivo, se tem de manter isenta de ideologia (nesse segundo sentido da palavra)...Precisamente através dessa sua tendência anti-ideológica se revela a teoria pura do Direito como verdadeira ciência do Direito...Como ciência, ela não se considera obrigada senão a conceber o direito positivo de acordo com sua própria essência e a compreendêlo através de uma análise de sua estrutura. Recusa-se particularmente a servir a quaisquer interesses políticos, fornecendo-Ihes as ideologias por intermédio das quais a ordem vigente é legitimada ou desqualificada.

Após a exposição pontual da concepção kelseniana acerca do Direito como ciência, cabem duas observações de extrema importância: a primeira é a delimitação necessária a tudo o que acabou de ser exposto- Kelsen, ao conceber uma ciência jurídica isolada de todo e qualquer valor não está de forma nenhuma defendendo uma aplicação não-valorativa do Direito, tão pouco definindo o Direito da mesma forma- Assim, há que se diferenciar o objeto da ciência do Direito- a norma jurídica, do Direito em si, como bem expõe Marcelo Guerra Martins (MARTINS,2009, p. 68):

É de se atentar que o Direito em si não é ciência.Ele pode ser objeto da ciência, isto é, suas prescrições podem ser investigadas de maneiras variadas e para diversas finalidades. Não há que se confundir o fenômeno com sua análise.Assim, a maçã que cai da árvore poderá ser objeto de observação pela ciência da mecânica desenvolvida por Newton, mas a fruta e as forças que sobre elas atuam em si não são ciência, mas , ao contrário, objetos dela.

Além disso, do ponto de vista da aplicação do Direito, Kelsen igualmente não propõe que essa ocorra de forma alheia aos valores sociais, pois de forma alguma o referido autor está distanciado do que efetivamente ocorre na realidade. Nesse sentido, sua obra também se propõe a analisar como as normas jurídicas são interpretadas quando da sua aplicação, ressaltando que os órgãos de aplicação da norma realizam o que Kelsen irá denominar interpretação autêntica, também chamada de política jurídica. ${ }^{34}$

\footnotetext{
${ }^{34}$ Até porque uma aplicação avalorativa da norma jurídica implicaria simplesmente na total desconsideração de todas as conquistas políticas materializadas nas constituições.Como expõe Martônio Barreto Lima: "Sem o componente da análise política, a aplicação das constituições a visão possível de seus direitos, garantias e instituições pouco contribuirão para sua própria existência, enquanto referência democrática a ser efetivada.Do ponto de vista acadêmico, é extremamente revitalizador observar que Hans Kelsen fornece elementos para tala afirmação e
} 
Por fim, cabe mencionar a intenção se Kelsen em evidenciar a negação da metafísica em sua teoria, uma vez que não prevê a existência de um valor absoluto, capaz de fundamentar a ciência jurídica, de maneira valorativa. Restam as palavras mais do que esclarecedoras de Karl Larenz(LARENZ, 1993,p. 86-88)acerca do projeto kelseniano:

As explicações de Kelsen só são compreensíveis, e, nesse caso absolutamente conseqüentes,s e se Ihes sotopõe o conceito positivista de ciência.Como se sabe, este exclui do campo da ciência toda metafísica e, por conseguinte, toda a Ética material e toda a teoria de valores.Como "ciências" só se reconhecem, por um lado, as ciências causais, que se baseiam na experiência, e, pelo outro, a lógica e a matemática, como teorias das "formas puras" dos corpos e dos números. Kelsen dá-se acertadamente conta de que a ciência do Direito não tem que ver, ou não tem primariamente que ver, com a conduta efectiva dos homens ou com os processos psicológicos em si mesmos, mas com as normas jurídicas e o seu conteúdo de sentido.Não pode, pois, ser uma ciência da natureza, uma ciência que descreva os fatos e investigue a sua ligação causal.Na medida em que constitua uma ciência só pode ser , para a concepção positivista de ciência, uma doutrina das "formas puras" do Direito.Nesse sentido, diz Kelsen que a jurisprudência não tem de curar senão da forma dos fenômenos, cabendo à sociologia e às disciplinas históricas o ocuparem-se do respectivo conteúdo; usando uma imagem, pode-se dizer que é uma "geometria do fenômeno jurídico no seu todo".Por isso, declarar os seus conceitos sem valor porque são necessariamente apenas formais, tem tão pouco sentido como criticar os conceitos da geometria "por abrangerem só formas dos corpos, sem se pronunciarem sobre o seu conteúdo.

\subsection{Direito Ambiental: possibilidades e impasses.}

O presente capítulo intenciona expor a segunda proposta de análise deste trabalho, qual seja, a "resposta" dada pelo Direito à necessidade de regulamentação entre as relações entre os seres humanos e a natureza, com destaque para o ramo do Direito intitulado "Direito Ambiental", bem como as possibilidades e os impasses desse ramo jurídico, ainda preso aos pressupostos da Modernidade.

A relação dos homens com o meio ambiente será, igualmente afetada pelas concepções anteriormente descritas e terá como conseqüência a dominação da natureza, uma vez que o homem se entende "hierarquicamente superior" aos demais seres, por ser racional dotado de vontade livre e, desse modo, distinto dos demais seres encontrados na natureza (que estão submetidos unicamente às suas relações de causalidade). Assim, sua intervenção no meio sempre

constatar, com certa tristeza, que o positivismo jurídico brasileiro reinante na grande parte das academias de direito do Brasil ignora o conjunto da obra de Kelsen, apenas reproduzindo passivamente parte de sua reflexões, reflexões estas, qu, empobrecidamente, não vão além de uma leitura desatenta da "Teoria Pura do Direito". (LIMA, p. 7) 
se revelou tão mais intensa quanto sua necessidade de "progresso" e de desenvolvimento, materializados no avanço das ciências, conforme já exposto.

Deve-se considerar, nesse contexto, a industrialização - e a conseqüente urbanização que foi o grande projeto econômico da sociedade burguesa, fundado exatamente na "dominação da natureza". A sociedade urbana e industrial levou a escalas inimagináveis a idéia central de dominação, fazendo da natureza um objeto, alvo da sujeição da sociedade. Nesse ambiente - e em visível contradição - surge o "Direito Ambiental".

Todavia, há muito que as conseqüências da ação humana no meio ambiente têm exposto os danos decorrentes dessa relação dominante do homem com a natureza, colocando em risco até mesmo a própria espécie humana, sem contar com os danos visíveis aos outros seres.

Nesse contexto é que a preocupação com um meio ambiente equilibrado começa e se manifestar, em conflito com o mote de dominação da natureza. Passa a ser a temática ambiental alvo de inúmeras atenções, de onde se observa a necessidade de se estabelecerem mecanismos institucionais aptos a garantirem a proteção ao meio ambiente. ${ }^{35}$

Surgirá, então, um ramo jurídico para expressar a referida preocupação, com o intuito de auxiliar na atenuação das conseqüências decorrentes da relação desequilibrada do homem com o meio ambiente.Mas não apenas isso: o novo ramo do Direito ora mencionado garante o direito ao meio ambiente como um direito humano, representando, nesse sentido, um avanço na questão ambiental.

Passa-se à análise das implicações decorrentes da emergência do direito ambiental, ressalvando-se desde já a importância de se atentar para a influência dos movimentos sociais para o advento do referido direito, como forma de tradução dos anseios sociais presentes nesses movimentos.

\footnotetext{
${ }^{35}$ Os marcos históricos para o tema em análise são muitos, mas entende-se que a preocupação como meio ambiente que delineará os contornos atuais da questão remonta a meados do século XIX, conforme expõe Zumira Batista: “(...) toda história do direito ambiental internacional está baseada em eventos que ocorreram no início do século passado e que começaram com a criação de decretos e leis que determinavam a proteção de espaços do meio ambiente considerados especiais, aos quais se denominavam parques ambientais.Esses parques tiveram origem no final do século XIX, em 1872, nos Estados Unidos.".(BAPTISTA,2005, p. 47)
} 
Como bem expõe Ronaldo Coutinho em seu artigo "Direito Ambiental das Cidades: Questões teórico-metodológicas", a emergência da codificação do Direito Ambiental de forma efetiva "é um "produto do próprio processo de ampliação do conteúdo dos direitos humanos", que decorre da expressão dos movimentos sociais por melhores condições de vida. Cabe a observação de Capelletti, também citada no artigo do professor Ronaldo Coutinho (CAPELETTI apud COUTINHO,2004, p. 32):

Para entender perfeitamente o tema é preciso, antes de tudo, abandonar o s esquemas dogmáticos e puristas. É necessário entender-se a questão social primeiro. Pois a questão social está na base dos interesses difusos. Só a partir daí se podem compreender os aspectos propriamente jurídicos.

Por sua vez, o direito ao meio ambiente, reconhecido na Conferência das Nações Unidas sobre o Ambiente Humano de 1972, reiterado na declaração do Rio sobre o meio ambiente e desenvolvimento de 1992, configura-se como uma extensão do direito à vida e a condições ambientais que garantam a dignidade da vida humana. Como bem coloca Cançado Trindade:

O caráter fundamental do direito à vida torna inadequados enfoques restritos do mesmo em nossos dias; sob o direito à vida em seu sentido próprio e moderno, não só se mantém a proteção contra qualquer privação arbitrária da vida, mas além disso encontram-se os Estados meios de sobrevivência a todos os indivíduos e todos os povos. Nesse propósito, tem os Estados a obrigação de evitar riscos ambientais sérios à vida.

Nesta linha também se insere o art. 225, da Constituição Federal de 1988:

Art. 225- Todos têm direito ao meio ambiente ecologicamente equilibrado, bem de uso comum do povo e essencial à sadia qualidade de vida, impondo-se ao Poder Público e à coletividade o dever de defendê-lo e preservá-lo para as presentes e futuras gerações

Entende-se a importância do novo status adquirido pelo direito ao meio ambiente, sem, contudo, deixar de se atentar para sua face nitidamente antropocêntrica: ao garantir o direito ao meio ambiente como um direito humano desconsidera-se os seres não humanos, presentes no meio ambiente. Estes, por sua vez, não estariam no escopo de abrangência de proteção das normas jurídicas.

Nesse sentido, faz-se imperioso repensar o próprio papel do Direito enquanto regulador dos comportamentos humanos no âmbito social, que se restringe à convivência dos homens com seus pares. Como bem pontua Édis Milaré (MILARÉ, 2009, p. 30): 
Com efeito, o foco do Direito ou da doutrina jurídica em última análise, não se volta para o mundo natural ou para as coisas, embora existam o Direito do Ambiente e o Direito das Coisas. O ambiente e as coisas são meramente elementos implicados nas relações entre as pessoas e nos objetivos da sociedade humana,Por si só, o Direito não conhece valor intrínseco do mundo natural bem como do fenômeno da vida e das suas teias.

De onde o autor conclui:

Convido que o ecossistema planetário (ou o mundo natural) tem valor intrínseco por força do ordenamento do Universo, não apenas valor de uso, estimativo ou de troca, é imperioso admitir que ele necessita de tutela do Direito, pelo que ele é em si mesmo, independentemente das avaliações e dos interesses humanos.

Observa-se então que o direito ambiental é ainda herdeiro do paradigma dominante, mas não só isso: tal visão antropocêntrica igualmente culminou em uma defesa do meio ambiente, apenas para garantir a satisfação das necessidades humanas, seja das gerações presentes e futuras. Nesse sentido, os "não humanos" encontrados na natureza e que são igualmente formas de vida não possuem valor algum frente à capacidade humana de subjugá-los

Aqui não se quer evidentemente sugerir o retorno a uma natureza "intocada", que, para ser conservada não deve sofrer nenhuma intervenção humana, pois, de resto, tal idéia se apresenta como um mito ${ }^{36}$, mas como se tentou expor ao longo do texto, é necessário, sim, rever a relação que os seres humanos estabeleceram com o meio ambiente.

Nesse sentido, entende-se que o Direito Ambiental, para além de seu alinhamento ao paradigma dominante será de grande valia para novas possibilidades de relação entre os seres humanos e o meio ambiente, pautando a regulamentação dessa relação não mais a partir de uma visão antropocêntrica, mas considerando igualmente os não humanos. Aqui cabem novamente as

\footnotetext{
${ }^{36}$ Aqui cabe mencionar a obra "o mito da natureza intocada", de Carlos Diegues, obra que se destina justamente a evidenciar como a idéia de proteção ambiental está ligada a falsa imagem de que essa proteção só será possível se não houver nenhuma intervenção humana na natureza. Em suas palavras: Para o naturalismo da proteção da natureza do século passado, a única forma de proteger a natureza era afastá-la do homem, por meio de ilhas onde ele pudesse admirá-la e reverenciá-la. Esses lugares paradisíacos serviriam também como locais selvagens, onde o homem pudesse refazer as energias gastas na vida estressante das cidades e do trabalho monótono.Parece realizar-se a reprodução do mito do paraíso perdido, lugar desejado e procurado pelo homem depois de sua expulsão do Éden.Esse neomito ou mito moderno vem impregnado, no entanto, do pensamento racional representado por conceitos como biodiversidade, ecossistema, etc. Como afirma Morin (1986), o pensamento técnico- racional ainda hoje se vê parasitado pelo pensamento mítico e simbólico.A existência de um mundo natural selvagem intocável e intocado faz parte, portanto, desses neomitos. Como afirma Ellen (1989) a natureza em estado puro não existe e as regiões naturais
} 
palavras de Bruno Latour (LATOUR, 2004, p. 232):

É porque, apesar de sua importância, não é feita menção ao direito. Com efeito, o direito sempre teve a cortesia de aceitar seu relativismo sem fazer disso um caso complicado. Ele sabe reconhecer, entre os outros, um direito simplesmente diferente; ele concorda em reunir positivamente realidade e ficção. Ele é o menos molhado, se ousamos dizê-lo do que a Ciência, a política ou a moral, na questão da natureza.

Entendemos, porém, que o "auxílio" do Direito à questão ambiental para ser efetivo, deverá igualmente vir acompanhado de uma análise crítica do modo de produção vigente ${ }^{37}$, uma vez que as exigências desse último (de consumo e de produção, que, por si só, já tem conseqüências diretas sobre a natureza) jamais permitiriam a qualquer outra relação, que não a utilitarista, dos seres humanos com a natureza.

\section{Conclusão}

O presente trabalho apresentou-se como uma tentativa de expor os principais aspectos da Modernidade, enquanto período histórico de ruptura descontínua, porque marcado por uma crise, que evidenciou os impasses do projeto "vencedor".

A partir dessa perspectiva, passou-se às principais modificações conceituais e filosóficas introduzidas e ou viabilizadas pela Modernidade, tais como a ciência, nos termos em que é entendida até os dias atuais, o conceito de cultura e sua oposição ao conceito de natureza.

apontadas pelos biogeógrafos usualmente correspondem a áreas extensivamente manipuladas pelos homens. (DIEGUES, 2000, p 13-14)

${ }^{37}$ Não optamos por abordar a questão sob a ótica marxista, reconhecendo, todavia, a importância de se considerarem os fatores econômicos, sobretudo, no que diz respeito ao modo de produção vigente (capitalista) para uma crítica não "alienada" acerca do Direito Ambiental. Sobretudo, das relações que o homem estabeleceu com o meio ambiente.Assim, consideramos pertinente a observação de Istaván Mezáros, a respeito da eficácia do Direito face ao modo de produção vigente: (..) a decretação formal em si não pode oferecer garantias de sua implementação, como testemunham de maneira ampla os inumeráveis princípios constitucional- democráticos solenemente proclamados e as incontáveis leis "que não pegam" e só adornam legislações.Pois elas "não pegam" precisamente porque pode, ou talvez pudessem, restringir o poder do capital (...) vive-se sob a pressão de explorar tudo ao máximo, desde os recursos não renováveis até os avanços eticamente mais questionáveis da biotecnologia e da informática, diretamente subordinados aos ditames da acumulação lucrativa do capital.Nesse mundo,apenas em sonho se poderia fazer oposição completa a esses desenvolvimentos por meio dos bons ofícios de uma legislatura iluminada. (MÉZÁROS, 2010, p. 142, 143) 
Sobre esse último aspecto, baseou-se a abordagem feita, com o intuito de evidenciar suas impossibilidades, seja pelas conseqüências práticas dessa divisão, seja pelo "estranhamento" causado , quando confrontamos tal divisão com outros seres humanos "não modernos", como se procurou expor no capítulo intitulado "Sugestão Antropológica: Antropocentrismo e Meio Ambiente".

Ainda sobre as "inovações" da Modernidade, apresentou- se as questões relativas à Ciência Moderna, com destaque para a ascensão e hegemonia do discurso científico, como o único capaz de "dizer a verdade" sobre o mundo, bem como os inconvenientes dessa forma de pensar.

Em um segundo momento, passou-se análise da influência do discurso Moderno no Direito, seja como "herdeiro" do paradigma da Modernidade em sua epistemologia ( tendo Hans Kelsen como representante), seja como mecanismo regulamentador das relações entre os seres humanos e o meio ambiente, uma vez que a utilização indiscriminada da natureza revelou tal necessidade de regulamentação.

No primeiro caso, foi apresentado o modo como Kelsen entendia a diferença entre as ciências naturais e o Direito, no que diz respeito ao "princípio regente" de cada um (causalidade nas ciências naturais e imputação no Direito) e, em que termos seria possível a idéia de uma ciência jurídica, considerando-se a diferença entre o princípio da causalidade (que opera no plano do ser) e o princípio da imputação (que opera no plano do dever ser).

No segundo caso, expôs-se a emergência do Direito ambiental, do ponto de vista histórico e epistemológico, evidenciando em que medida esse ramo do Direito rompe com os pressupostos Modernos, ao mesmo tempo que se alinha a eles.

Resta saber quais são as possibilidade frente às promessas e aos impasses da Modernidade. O questionamento a ser feito passa a ser então o seguinte: como, a partir do "outro" que são os modernos podem revisar seus conceitos?

Até agora, nada se falou sobre as instituições modernas que se deseja manter. A crítica feita relativamente a um determinado modo de se conhecer a partir da Modernidade não deve impedir que se atente para algumas possibilidades de organização política que se revelam muito úteis para pensar o mundo comum dos humanos e da natureza. 
Esses aspectos evidentemente fazem parte de uma Modernidade pouco explorada, face aos acontecimentos (selecionados?) que se tornaram característicos do período. Nesse sentido, é necessária a compreensão da Modernidade não mais a parir de acontecimentos homogêneos e sim de marchas e de contramarchas, rupturas e permanências (como reações ao "novo").

O que se precisa reconhecer é a importância dos modos de pensar instaurados a partir desses valores, a saber, a consciência de que existe um espaço público a ser compartilhado e constantemente discutido e que todos os cidadãos(humanos e não humanos) têm o direito de falar e de participar dos processos de gestão do espaço público.

A questão que se coloca, por sua vez, é a seguinte: Como estender os conceitos de república e de democracia à relação entre os humanos e os não humanos?Conceber a existência de um mundo comum pertencente a todos não possui grandes dificuldades, mas como entender o que os não humanos dizem?Quais as negociações e contratos possíveis com eles?

O paradigma científico atribuiu aos cientistas o lugar de portadores do discurso sobre o não humanos. A reforma de tal concepção estaria, então, no fato de se pensar os cientistas como representantes dos não humanos, o que permite uma dúvida constante sobre seus enunciados, bem como a possibilidade de discuti-los.

Longe de desqualificar o discurso científico, o que se está propondo é uma avaliação pragmática de seus efeitos, pois, em última análise, a "linguagem do mundo" estará sempre condicionada às relações que estabelecemos com ele. Nas palavras de Michel Serres, citado por Bruno Latour (SERRES apud LATOUR, 2004, P. 84):

Certamente, ignoramos a linguagem do mundo, ou não conhecemos dela senão versões animistas, religiosas ou matemáticas. Quando foi inventada a física, os filósofos foram dizendo que a natureza se escondia sob o código dos números ou das letras da álgebra: este termo-código vinha do direito. Na realidade, a Terra nos fala em termos de forças, ligações e interações e isto basta para fazer um contrato

Acabou a natureza, a cultura e o homem?De forma alguma, mas, sem dúvida se faz urgente recolocá-los. Evidentemente, distinções ainda são necessárias e se é preciso manter a cultura como "mito fundador" da espécie humana, que isso não faça a humanidade se esquecer de que ela convive com uma infinidade de não humanos e que precisa reconhecer isso, bem como 
institucionalizar regras de convivência- a cultura e a natureza, nesse sentido não necessitam de temor mútuo e sim de um diálogo,pois ocupam um mesmo espaço.

Desse modo, mais do que meras "inovações" internas, o Direito Ambiental expõe a urgência de uma nova conceituação do próprio papel do Direito nas sociedades contemporâneas, de ser uma expressão efetiva dos anseios sociais, esses sendo compreendidos não apenas no âmbito das sociedades humanas, mas de todos os seres que habitam o meio ambiente juntamente com o homem.

Além disso, é preciso instaurar uma nova temporalidade em relação às associações humanas com a natureza, uma vez que a rapidez na qual ocorre aliada ao fato de aparecerem (apesar de não reconhecidas) de forma benéfica "rumo ao progresso" não permite pensar sobre seus efeitos, tampouco sobre a relatividade das práticas modernas, que acabam por se inscrever no campo que é "natural" ou a única possibilidade.

Se caminhos para um diálogo com as coisas ainda se mostram abstratos, é devido à falta de uma prática experimental, que possa indicar alternativas à epistemologia hegemônica que tem na crença na existência de uma total separação entre os "homens" e "os outros" seu ponto cego ou o lugar em que as Luzes tão desejadas para retirar a humanidade do obscurantismo das épocas passadas parecem não terem chegado.

Entende-se, tal qual Bruno Latour, que a visão aqui exposta é, sim, um ponto de vista, que pode ser considerado, no mínimo, ocidental. Mas, aqui também as palavras desse autor (LATOUR, 2004, p. 359) são pertinentes: “Mas onde já se viu um diplomata que não leve os estigmas do campo que ele representa? Quem não se reveste da capa dos interesses poderosos que ele escolheu para servir, e portanto, trair?" E por fim:

Acreditou-se que o melhor dos mundos possível era calculável, com a condição de bloquear o trabalho da política. Era suficiente para arruinar todas as outras virtudes, tanto heroísmo teria sido necessário para resistir às armadilhas dessa facilidade.Ora, nem Deus, nem os homens, nem a natureza têm a capacidade soberana de efetuar de imediato esse cálculo.Este "nós' precisa produzir todas as partes. Nenhuma fada nos disse como. A nós compete descobri-lo.(LATOUR, 2004, p. 272) 


\section{Bibliografia}

AGOSTI, Hector. Ideologia e cultura. Lisboa: Livros Horizonte, 1984. 
ASSIS, Vivian Alves de. A dimensão mítica da pureza metodológica em Kelsen : uma leitura a partir da proposta transurrealista de Luis Alberto Warat. Dissertação (Mestrado em Direito).Pontifícia Universidade Católica do Rio de Janeiro, Rio de Janeiro, 2008 Disponível em : $<$ http://www2.dbd.pucrio.br/pergamum/biblioteca/php/mostrateses. php?open=1\&arqtese=0610 354_08_Indice.html>. Acesso em : 6 outubro de 2011.

BAPTISTA, Zulmira M. de Castro. Direito Ambiental Internacional. Política e Conseqüências. São Paulo: Editora Pillares, 2005.

BOBBIO, Norberto. O Positivismo Jurídico: Lições de Filosofia do Direito. Tradução e notas Márcio Pugliese, Edson Bini, Carlos E. Rodrigues. São Paulo: Ícone, 1995.

CAPELLA, Juan Ramón. Os Cidadãos Servos. Tradução Lédio Rosa Andrade e Têmis Correia Soares; Porto Alegre: Sérgio Fabris, 1998.

CHAUÍ, Marilena.Convite à Filosofia.São Paulo:Ática,2003.

COUCHE, Denys.A noção de cultura nas ciências sociais.São Paulo:edusc,2003.

COUTINHO, Ronaldo. Direito Ambiental das Cidades: Questões teórico- metodológicas.In: ROCCO, Rogério (orgs.).Direito Ambiental das Cidades.Rio de Janeiro: DP \& A Editora, 2004.

DELEUZE,Gilles.Correspondência de Gilles Deleuze a Michel Cressole.In:CARRILHO,Manuel Maria.Capitalismo e esquizofrenia:dossier Anti-Édipo.Lisboa:Assírio e Alvin,1976.

DIEGUES,Antônio Carlos Santana.O Mito Moderno da Natureza Intocada.São Paulo:Hucitec, 2000.

EAGLETON, Terry. A Idéia de Cultura. Tradução Sandra Castello Branco.São Paulo: UNESP, 2003.

ELIADE, Mircea.O mito do eterno retorno:arquétipos e repetição.Lisboa:edições 70,1993

KELSEN, Hans. O que é Justiça. Tradução de Luís Carlos Borges. São Paulo: Martins Fontes, 2001.

Teoria Pura do Direito. Tradução de João Baptista Machado; São Paulo. Martins

Fontes. 2003

KEHL, Maria Rita.O tempo e o cão:a atualidade das depressões.São Paulo: Boitempo,2009

LARENZ, Karl. Metodologia da Ciência do Direito. Tradução de José Lamego.Lisboa: Fundação Calouste Gulbenkian, 1993.

LATOUR, Bruno.Jamais Fomos Modernos.São Paulo:Editora 34,2005. .Políticas da Natureza:como fazer ciência na democracia.Bauru:EDUSC,2004. 
LIMA, Carlos Eduardo de Araújo. Permanência e Mutabilidade em Hans Kelsen. Rio de Janeiro: Lumen Juris, 1995.

LIMA, Marcelo Mont`alverne Barreto. A Guarda da Constituição em Hans Kelsen.Disponível em: <http://xa.yimg.com/kq/groups/21812352/1652290874/name/Montalver...pdf>Acesso em: $30 / 10 / 2011$.

LOWY,Michel.Ideologias e ciência social:elementos para uma análise marxista.São Paulo:Cortez,2003

MARTINS, Marcelo Guerra. Democracia fiscal e seus fundamentos a luz do direito e da economia. Tese de Doutorado em Direito. Universidade de São Paulo: São Paulo, 2009. Disponível em:<http://www.teses.usp.br/index.php?option=com jumi\&fileid=20\&ltemid=96\&lang=pt-

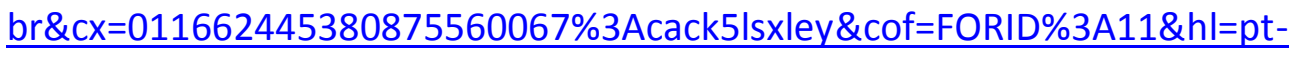
$\underline{b r \& q=M a r c e l o+G u e r r a+M a r t i n s \& s i t e u r l=w w w . t e s e s . u s p . b r \% 2 F i n d e x . p h p \% 3 F o p t i o n \% 3 D c o m ~ j u m i ~}$ \%26fileid\%3D20\%26Itemid\%3D96\%26lang\%3Dpt-br\#1004>Acesso em: 3/11/2011.

MÉSZAROS, István. Atualidade Histórica da Ofensiva Socialista. Tradução Paulo Cezar Castanheira; São Paulo: Boitempo, 2010.

MILARÉ, EDIS. Direito do Ambiente: A gestão Ambiental em foco.São Paulo: Revista dos Tribunais, 2009.

MORIN, Edgard.Ciência com consciência.Rio de Janeiro:Bertrand Brasil,2008

NEGRI, Antonio e HARDT, Michael. Império. Tradução de Berilo Vargas. Rio de Janeiro: Record,2001.

Multidão. Guerra e Democracia na era do Império.Tradução de Clóvis Marques.Rio de Janeiro: Record, 2005

QUINTANA, Fernando. O desafio do novo milênio:Universalismo e/ou particularismo ético?.In:GUERRA,Sidney(coord).Direitos humanos:uma abordagem interdisciplinar.Rio de Janeiro:América Jurídica,2002.

SANTOS, Boaventura de Souza.Um discurso sobre as ciências.São Paulo:Cortez,2004

SERRES Michel. O Contrato Natural. Tradução de Beatriz Sidoux. Rio de Janeiro: Nova Fronteira, 1991. 
SGARBI, Adrian. Hans Kelsen: Ensaios Introdutórios (2001-2005). Vol I. Rio de Janeiro: Lumen Juris, 2007.

SKINNER, Quentin. As Fundações do Pensamento Político Moderno. Tradução Renato Janine Ribeiro e Laura Teixeira Motta. São Paulo: Companhia das Letras, 1996.

RIBEIRO,Fernando Fagundes.Somos todos psiquiatras:a genealogia do poder perante os saberes do homem e o corte epistemológico.In:CRUZ,Nina Velasco e QUEIROZ,André(org).Foucault,hoje?.Rio de Janeiro: 7 Letras,2007.

VIVEIROS DE CASTRO, Eduardo. A inconstância da alma selvagem. Rio de Janeiro:Cosacnaify,2008. 